\title{
SIMEON OF QAL'A RUMAITA, PATRIARCH PHILOXENUS NEMROD AND BAR ${ }^{e} E B R O Y O$
}

\author{
HIDEMI TAKAHASHI \\ J.W. GOETHE-UNIVERSITÄT FRANKFURT \\ FRANKFURT AM MAIN \\ GERMANY
}

\begin{abstract}
An attempt is made in this article to throw some light on the circumstances in which Bar 'Ebroyo (Barhebraeus) worked by focusing our attention on the priest-physician Simeon b. Joshua of Qal'a Rumaita (ob. 1289), who rose to a position of some importance at the Ilkhanid court in the 1260's and whose nephew Nemrod became patriarch under the name of Philoxenus in 1283. The fact that two of Bar 'Ebroyo's works are dedicated to this Simeon suggests that he may have played an important role in the background to Bar 'Ebroyo's literary activity.
\end{abstract}

\section{INTRODUCTION}

[1] The innumerable accounts of the life of Bar Ebroyo (Barhebraeus) which have been written to date have a tendency to repeat each other and only a few go far beyond the framework already set by 
the account in J.S. Assemani's Bibliotheca Orientalis (II.244-321). ${ }^{1}$

1 A list of some forty "bio-bibliographical" works on Bar "Ebroyo published up to 1986 may be found on pp. 280-4 in J.M. Fiey, "Esquisse d'une bibliographie de Bar Hébraeus (+1286)," ParOr 13 (1986): 279-312. It is needless to say that most editions and translations of Bar 'Ebroyo's works also contain accounts of varying lengths dealing with his life and works in their introductions. To the list at pp. 280-4 in Fiey, one might, without even attempting to be exhaustive, add such items as: E. Renaudot, Liturgiarum orientalium collectio (Frankfurt: Baer / London: Leslie, 18472), II.467-470; F. Nève, L'Arménie chrétienne et sa littérature (Louvain: Peeters / Berlin: Mayer \& Muller / Paris: Leroux, 1886) 388-93; Y.I. Dibs, Târîkh Sûrîya al-dunyawî wa-l-dînî, 8 vols. (Beirut: al-Matba ${ }^{c}$ al-'Umûmîya alKâthûlîkîya, 1893-1905) VI, 348-57; M. Jugie, Theologia dogmatica Christianorum orientalium ab Ecclesia Catholica dissidentium, vol. V (Paris: Letouzey et Ané, 1935) 474-8; G.S. Shameûn, "Âfâq al-maerifa einda Ibn al-'Ibrî," alMajalla al-batriyarkîya (Damascus) 2 (1963): 485-99, 535-44; N. Rescher, The Development of Arabic Logic (Pittsburgh: Pittsburgh University Press, 1964) 206f. (horrendously inaccurate, but mentioning one or two otherwise overlooked references); A. Vööbus, Syrische Kanonensammlungen. Ein Beitrag zur Quellenkunde, I (CSCO, 307, 317, subs. 35, 38; Louvain: Secrétariat du Corpus CSO, 1970) 499-506; L. Cheïkho and C. Hechaïmé, 'Ulamẩ al-nașrânîya fî al-Islâm 622-1300 (PAC, 5 ; Jounieh: Librairie St. Paul / Rome: Pont. Istituto Orientale, 1983) 75-7; W. Hage, "Gregorius Barhebräus," in M. Greschat (ed.), Gestalten der Kirchengeschichte, vol. 4 (Stuttgart/Berlin/Cologne/Mainz: Kohlhammer, 1983) 63-72; 'U.R. Kahhâla, Al-mustadrak 'alâ Muejam al-mu'allifìn (Beirut: Mu'assasat al-Risâla, 1985) 535 (addenda to id., Mu jam al-mu'allifin 8 [1959]: 39f.); Y.M. Ishâaq, "Mașâdir Abî al-Faraj al-Malaṭi al-târîkhîya wa-atharhâ fî manâhijihi," Journal of the Iraq Academy, Syriac Corporation 11 (1987): 70-118, = id., Aram (Oxford) 1 (1989): 149-72; Hage, Syriac Christianity in the East (Moran 'Eth'o, 1; Kottayam: SEERI, 1988, rep. 1997) 83-96; M.J. Panicker, "Christology of Bar Ebraya (Yuhanon Gregorius Abu'l Faraj)" (Diss. Rome, PIOS, 1994) 6-55 (unpublished, reference taken from the excerpt of the dissertation published under the same title [Rome, 1995], 93f.); G.Y. Ibrâhîm, "Mâr Ghrîghûriyûs Yûhannâ Ibn al-'Ibrî 1226-1286," = intro. to D.B. Jijâwî, Manârat al-aqdâs li-l'allâma Mâr Ghrîghûriyûs Abî alFaraj Ibn al-'Ibrî mafriyân al-mashriq 1226-1286 (Aleppo: Mardin Publishing House, 1996) 1-41; A. Sauma, "Det syrianske författargeniet Johannes Bar Hebraeus 1226-1286," Aram (Stockholm, Arameiska Akademikernas Förbund) 10-12 (1996): 10-36; S.P. Brock, A Brief Outline of Syriac 
The appearance, therefore, in a previous volume of the Hugoye of an article by G. Lane, where an attempt is made to take greater account than usual of the historical circumstances under which the great maphrian lived and worked, might, in this respect, be considered a welcome event. ${ }^{2}$ A comprehensive biography of Bar

Literature (Moran 'Eth'o, 9; Kottayam: SEERI, 1997) 75-80 et passim; E.-I. Yousif, Les philosophes et traducteurs syriaques. D'Athènes à Baghdad (Paris/Montreal: Harmattan, 1997) 143-53, along with such encyclopedia articles as P. Bayle, DHC (Rotterdam, 16971), ed. Amsterdam 1740, I.37; B. d'Herbelot, Bibliothèque orientale (Paris, 16971), ed. The Hague 1777-9, I.31, II.157, IV.690 (addition by H.J. Schultens); [A.G.] Hoffmann, AEWK I/7.384-6 (1821); P. Bötticher [= de Lagarde], RE 1.91-4 (1854); P. de Lagarde, RE ${ }^{2}$ 1.110f. (1877); A. Socin, RE ${ }^{3} 1.123 f$. (1896, addenda at 23.5, 1913); M. Seligsohn—R. Gottheil, JE 6.91 (1904); J. Heller, EJ(D) 3.1074f. (1929); J. Göttsberger, LThK 1.967-9 (1930); G. Furlani, EncIt 6.176f. (1930); G. Ricciotti, EC 2.542f. (1949); C. Brockelmann, IslAns 5.861f. (1950, = tr. of EI 1.684f.); J. Mécérian, LThK² 4.1207 (1960); W. Hage, TRE 14.158-64 (1985); anon., DHGE 21.1483f. (1986, addenda to Hermann's article at DHGE 6.792-4); K. Samir, The Coptic Encyclopedia (New York/Toronto: Macmillan, 1991), 345f.; S. Griffith, The Oxford Dictionary of Byzantium (New York/Oxford: Oxford University Press), 2.878f. (1991); S.P. Brock, LThK ${ }^{3}$ IV.1001f. (1995); H. Teule, EIr 8.13-15 (1997); and A. Özaydin, IslAns² 21.92-4 (2000).Among the numerous studies on the life of Bar ${ }^{\mathrm{e}}$ Ebroyo in European languages, the "sketch" in T. Nöldeke, Orientalische Skizzen (Berlin: Paetel, 1892, rep. Hildesheim: Olms, 1974) 253-73 remains one of the most readable and the study by J. Göttsberger in his Barbebräus und seine Scbolien zur Heiligen Schrift, BSt $(\mathrm{F})$ 5/4-5 (Freiburg: Herder, 1900) 5-56, one of the most thorough. It is unfortunate that the accounts written in English tend to be marred by inaccuracies. A particular warning is due against the account in the introduction to W.E.W. Carr, Gregory Abu'l Faraj, commonly called Bar-Hebraeus. Commentary on the Gospels from the Horreum Mysteriorum (London: SPCK, New York/Toronto: Macmillan, 1925), which frequently betrays an inability even to read simple Latin on Carr's part. The introduction to E.A.W. Budge, The Chronography of Gregory Abû̀l Faraj, the son of Aaron, the Hebrew physician, commonly known as Bar Hebraeus (Oxford: OUP, London; Humphrey Milford, 1932), on which Lane depends heavily (v. infra n. 2), is somewhat, but not much, better.

${ }^{2}$ G. Lane, "An Account of Gregory Bar Hebraeus Abu al-Faraj and his Relations with the Mongols of Persia," Hugoye 2.2 (July 1999). 
'Ebroyo, however, which takes full account of the materials made available since Assemani's day and which is at the same based on trustworthy primary sources rather than on second and third-hand information and unreliable translations, remains a work to be written.

As a small contribution to the composition of such a biography, an attempt is made in this brief article to throw some light on the circumstances in which Bar ${ }^{e}$ Ebroyo worked by focusing our attention on the Syriac Orthodox priest-physician Simeon of Qal'a Rûmâitâ (Rum Kale, Hromkla), who rose to a position of some importance at the Ilkhanid court in the 1260's and to whose patronage and encouragement we may owe a number of Bar 'Ebroyo's works.

\section{SIMEON OF QAL ${ }^{e}$ A RUMAITA AND PATRIARCH Philoxenus NeMrod}

In the first, political part of Bar 'Ebroyo's Syriac chronicle (= Chron.), we find the following passage devoted to Rabban Simeon of Qalea Rumaita. ${ }^{3}$

${ }^{3}$ Bar Ebroyo, Chron., ed. P.J. Bruns \& G.G. Kirsch, Bar-Hebraei Chronicon syriacum (Leipzig: Boehme, 1789) 534.18-535.3; ed. P. Bedjan, Gregorii Barbebraei Chronicon syriacum (Paris: Maisonneuve, 1890) 512.9-16; ed. Budge (1932) [v. supra n. 1], vol. II (= ms. Bodl. Hunt. 52) 158v a924; ed. J.Y. Çiçek, The Chronography of Bar Hebraeus (Glane/Losser: Bar Hebraeus Verlag: 1987) 463a 10-23; tr. Budge, op. cit., I.437; tr. D. Ömer Riza, Gregory Abû'l-Farac (Bar Hebraeus). Abû̀l-Farac Taribi, TTKY 2/2 (Ankara 1945-50, rep. Ankara: Türk Tarih Kurumu Basimevi, 1987) 576 (= [mis-]translation of tr. Budge); tr. I. Armalet, "Târîkh al-duwal alsuryânî ta'lîf Abî al-Faraj al-Malațî," in Machriq vols. 43-50 (1949-56), here 50 (1956) 138.10-14; cf. also R. Gusejnov, Sirijskie istocniki XII-XIII vv. ob Azerbajdz̧ane (Baku: Izd. Akademii Nauk Azerbajdzzanskoj SSR, 1960) 76, 133 (with Russian translation of the passage based on ed. BrunsKirsch); J.M. Fiey, Chrétiens syriaques sous les Mongols (Il-Khanat de Perse, XIIIe-XIV e s.), CSCO 362, subs. 44 (Louvain: Secrétariat du Corpus CSO, 1975) $[=1975 \mathrm{a}] 25 \mathrm{f}$. 
In those days [i.e. ca. $1260^{4}$ ] Rabban Simeon, the priest $^{5}$ and physician, the son of the late Joshua, the priest, of Qal'a Rumaita, entered the service of the King of Kings, Hulagu. ${ }^{6}$ He became very powerful and famous, and was loved by all the sons of kings and queens. He possessed regal mansions, gardens, parks and towers ${ }^{7}$ in Maragha and had an annual income of 5,000 dinars from Babel, Athor, Cappadocia and Maragha itself. The rest of our people obtained through him help, a great 'lifting of head' and honour, ${ }^{8}$ and our church stability and protection in every place.

The revenue of 5,000 dinars mentioned here may not be in the league of those of the highest officials at the Ilkhanid court, ${ }^{9}$ but it

4 The date 27.9.658 A.H. mentioned at Chron. [Bedjan] 512.21f. corresponds to 5th Sept. 1260 A.D., not "A.D. 1259" as Budge has it in his translation (438.3).

5 "qashisho:" tr. Budge, infeliciter: "Simeon/Îshô c the Elder;" and following him Fiey: "Simon/Icho' l'Ancien."

${ }^{6}$ Cf. Chron. eccl., ed. J.B. Abbeloos \& T.J. Lamy, Gregorii Barbebraei Chronicon ecclesiaticum (Louvain: Peeters, 1872-7), I.735 ("Simeon ... had recently come to serve the King of Kings").- - The phrase "l-teshmeshto damlek malke" at I.735.4 is translated as "ad salutandum regem regum" by Abbeloos-Lamy and is also taken in this sense by P. Kawerau, Die jakobitische Kirche im Zeitalter der syrischen Renaissance. Idee und Wirklichkeit (Berlin: Akademie-Verlag, 19602) 101. Despite the use of "l-teshmeshto" in the sense of "to pay homage" with reference to Dionysius "Angur a few lines earlier at Chron. eccl. I.733.penult. and elsewhere (e.g. Chron. eccl. I.765.4, 775.14, II.433.16), the phrase at I.735.4 should be understood in the sense of "to serve" in view of the passage here (i.e. Chron. 512.10, cf. also Chron. eccl. I.747.6).

7 "w-furkoso:" om. ed. Bruns-Kirsch (based on Bodl. Hunt. 52, see R. Payne Smith, Catalogi codicum manuscriptorum Bibliothecae Bodleianae pars sexta [Oxford: Clarendon, 1864], 396; Budge, op. cit., II.vi) et ed. Budge (= ms. Bodl. Hunt. 52).

8 "a great 'lifting of head', help and honour" (rim risho rabo w- 'udrono wiqoro): edd. Bruns-Kirsch et Budge.

9 The Ilkhanid chief and finance minister Shams al-Dîn Juwainî (ob. 1284, brother of the historian 'Alâ' al-Dîn 'Ațâ-Malik) is reported, in one account, to have had an annual income of 360 tûmân $(=3.6$ million silver dinars) (B. Spuler, Die Mongolen in Iran. Politik, Verwaltung und Kultur der Ilchanzeit 1220-1350, 4th ed. [Leiden: Brill, 1985], 72, citing Wașṣâf, 
is unusually high for a physician and as such suggests a position of some consequence at the court. ${ }^{10}$ The passage also suggests that Simeon must have exercised considerable influence in the affairs of the Syriac Orthodox Church as the representative of her interests at the Ilkhanid court. We know, in fact, from the latter part of Bar 'Ebroyo's chronicle, the Chronicon ecclesiasticum (= Chron. eccl.), that Simeon played a leading role in the reactions at the Ilkhanid court to the series of events surrounding the assassination of Patriarch Dionysius Aaron 'Angur (1253-61), ${ }^{11}$ and that Simeon and his family were also engaged in a seemingly endless conflict with Patriarch Ignatius IV (III) Joshua (1264-83) over the control of the Monastery of Mâr Barșawmâ. ${ }^{12}$

Tajziyat al-amsâr wa-tajziyat al-åșâr, ed. Bombay 1852/3, I.56, but cf. Spuler, "Djuwaynî, Shams ad-Dîn ...," EI II II.607; on the unit "tûmân," see Spuler [1985] 255; R.E. Darley-Doran, "Tûmân 2.," EI² X.619-621). The taxreturns received by the Ilkhanid diwan in the period before the economic reforms of Ghazan Khan (1295-1304) have been reckoned at 17-18 million dinars (I.P. Petrushevsky, "The Socio-Economic Conditions of Iran under the Îl-Khâns," in The Cambridge History of Iran, vol. 5 [Cambridge: CUP, 1968] 483-537, here 497).

${ }^{10}$ For examples of the remunerations of physicians under Islam, see E. Ashtor, Histoire des prix et des salaires dans l'Orient médiéval (Paris: S.E.V.P.E.N., 1969) 68f., 94, 228, 263f., 378, 532. Assuming that gold dinars are meant, Simeon's income mentioned here approaches those reported of the famous court physicians at the height of the Abbasid caliphate, such as Jibrầîl b. Bukhtîshûe with a salary of 500 dinars per month and rations worth 5000 per annum under Hârûn al-Rashîd, and Hunain b. Ishâaq with a monthly pay of 700 dinars under al-Mutawakkil (op. cit., 68f.). - A part, at least, of Simeon's income may have come from those Islamic religious endowments (awqâf), whose revenues are stated to have been diverted to the payment, among others, of "Christian and Jewish physicians," a practice which was forbidden by the convert-Muslim Ahmad Khan (Tegüder, 1282-84) (Spuler [1985] 179, 199, 273f., citing Wașâff, Tajzizat al-amsâr, ed. J. von Hammer-Purgstall, Vienna 1856, I.225f. and Mîrkhwând, Rawdat al-safâ’, ed. Bombay 1849/50, V.99).

${ }_{11}$ Chron. eccl. I.735.1-ult., 741.3-13; cf. also I.695.1 ("Simeon"), 4 ("sons of Joshua").

12 Chron. eccl. I.759-61, 763-9; cf. E. Honigmann, Le couvent de Barsaumâ et le patriarcat jacobite d'Antioche et de Syrie, CSCO 146, subs. 7 (Louvain: Durbecq, 1954) 72f.; Kawerau (1960) 40, 51, 88. 
Another piece of evidence concerning the influence of Simeon, however, seems to have escaped the notice of, or at least not to have been fully appreciated by, most European scholars, namely that Simeon was also an uncle of Patriarch Philoxenus (aliter Ignatius V [IV]) Nemrod (1283-92), as well as being a brother of Jacob, the contentious abbot of Mar Barșawma. ${ }^{13}$ The point is at any rate not mentioned where it might have been by such scholars as Th. Nöldeke, J. Göttsberger, H. Koffler and J.M. Fiey, ${ }^{14}$ while P. Kawerau, as we shall see, quite misunderstands the relationship between these three men and B. Spuler goes one step further by managing to confuse our Simeon with the East Syrian monk Simeon Rabban Ata who flourished a generation earlier. ${ }^{15}$

Patriarch Ignatius Ephrem I Barșaum, on the other hand, was well aware of the true nature of the relationship between Simeon, Jacob and Philoxenus Nemrod, as we may see from the section devoted to Simeon's family, the Bet Tuma Madnhoyo, in his work on the history of Tur 'Abdin. ${ }^{16}$ There the learned patriarch informs us on the basis of a Beirut manuscript (which may now be

13 The name of Philoxenus Nemrod's father, Abraham, though not mentioned in Chron. eccl., can be supplied from ms. Cantab. Dd $3.8^{2}$ (W. Wright-A. Cook, A Catalogue of the Syriac Manuscripts Preserved in the Library of the University of Cambridge [Cambridge: CUP, 1901] 986f.).

14 Nöldeke (1892) 260f., 265, 269; Göttsberger (1900) 18f., 22; H. Koffler, Die Lebre des Barbebräus von der Auferstebung der Leiber (Rome: PIOS, 1932) 38f.; Fiey (1975a) 25f.-E. Honigmann seems at least to have construed the relationship correctly, but he too does not press the point (Honigmann [1954] 68f., 72f.).

${ }^{15}$ Spuler (1985) 169f. (note the reference there in p. 170 n. 50 to Cbron. eccl. II [1 761-9).- Spuler's statement that Simeon Rabban Ata retired to a monatery in Mesopotamia around 1265 evidently involves further confusion, this time with Theodore of Quplida (see Chron. eccl. I.767.26f., cf. n. 56 below).

16 I.E. Barșaum, Maktbonuto d-'al atro d-Tûr 'Abdin (with Arabic translation by G.B. Behnam) (Jounieh: Biban, 1964, rep. of Syriac part only Glane/Losser: Bar Hebraeus Verlag, 1987) Syr. 163-5 (= Arab. 348350); cf. id., Al-lu'lu' al-manthûr fì târkh al-ulum wa-lâdâb al-suryânîa (Homs, 1956², rep. Glane/Losser: Bar Hebraeus Verlag, 1987) 407, no. 229 (also 135, no. 24, 163, no. 38). 
identified as Charfeh, fonds patriarcal/Rahmani 41 Sony) ${ }^{17}$ that the family of Simeon originated from Hesnâ d-Kêphâ (Hasankeyf), ${ }^{18}$ that Simeon's father Joshua (ob. 1247) ${ }^{19}$ had studied under Bishop Iwannis of $\mathrm{Ra}^{\mathrm{e}} \mathrm{ban}^{20}$ in Melitene and that he had been appointed priest of the newly-built Church of Our Lady in Qal'a Rumaita in 1235 by Patriarch Ignatius III (II) David the "Sâbâ" (1222-52). ${ }^{21}$ At an earlier point in the same work, Barșaum identifies Joshua with the translator of the Chronicle of Michael I the Elder into

17 See B. Sony, Fibris al-makbtuntatat al-batriyarkîya fì Dair al-SharfaLubnân (Beirut, 1993) 22 (olim 250 sec. Sony's concordance, ibid., p. 444, but it does not match the ms. given under that number by P. Sherwood, "Le fonds patriarcal de la bibliothèque manuscrite de Charfet," OrSyr 2 [1957]: 93-107, here p. 102, 106).—The information used by I.E. Barșaum is given in a colophon on fol. 6. In another colophon, at the end of the anaphora of Patr. Michael I (fol. 1, the text of the anaphora itself is missing), Joshua tells us that he had seen and had been blessed by the patriarch in his childhood, which allows us to place Joshua's birth at the latest a few years before 1199 .

${ }^{18}$ Joshua's full name with the patronymics would be Joshua b. Jacob b. David b. Simeon b. Tayyib (cf. Sony [1993] loc. cit.).-Gusejnov (op. cit. [1960], index p. 171) is clearly wrong in identifying our Simeon with the physician Simeon Heșnâyâ mentioned as the restorer of the Monastery of Mar Cyriacus near Heșnâ d-Zaid in 1207 at Chron. eccl. I.723.20f. (cf. Kawerau [1960] 51, 65, 119), since the date 1207 is too early for our Simeon (and too late for his great-great grandfather), while the nisba Heșnâyâ most probably refers to Heṣnâ d-Zaid rather than Heșnâ dKêphâ.

19 The date of Joshua's death, 14th Sept. 1247, which was unknown to Barșaum, may be supplied from a colophon in ms. Vat. Borg. syr. 159 (A. Scher, "Notice sur les manuscrits syriaques du Musée Borgia, aujourd'hui à la Bibliothèque Vaticane," $J A 10^{e}$ sér. 13 [1909]: 249-87, here 283; cf. A. Schmidt, "Die zweifache armenische Rezension der syrischen Chronik Michaels des Großen," Muséon 109 [1996]: 299-319, here 306).

${ }^{20}$ On whom, see J.M. Fiey, Pour un Oriens Christianus novus. Répertoire des diocèses syriaques orientaux et occidentaux, Beiruter Texte und Studien 49 (Beirut/Stuttgart: Steiner, 1993), 258.

${ }^{21}$ Cf. Chron. eccl. I.665.21-667.5. 
Armenian (or, to be precise, the co-translator, along with Vardan Arewelc'i, of one of the two Armenian versions). ${ }^{22}$

The passage which has been the cause of much misunderstanding is the following.

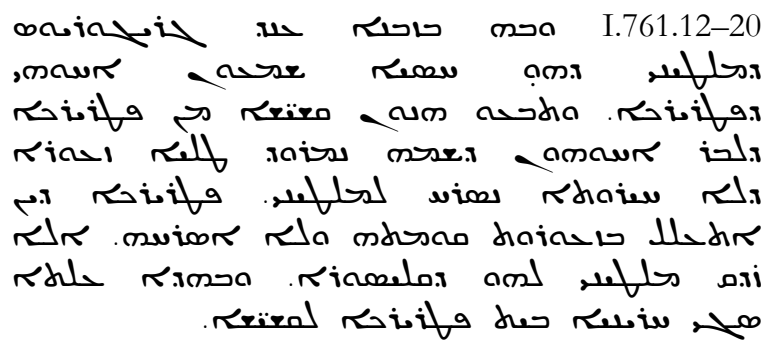

22 Barșaum (1964) Syr. 153 (= Arab. 337); cf. id., Lu’lu’, loc. cit. supra in n. 16.-On the Armenian version(s) of Michael's Chronicle, see A. Schmidt (1996) along with the literature listed at R.W. Thomson, A Bibliography of Classical Armenian Literature to 1500 AD (Turnhout: Brepols, 1995) 69f.; cf. also Schmidt, "Syrische Tradition in armenischer Adaption. Die armenische Rezeption des Geschichtswerks von Michael Syrus und der antichalcedonische Judenbrief an Kaiser Markianos," in R. Lavenent (ed.), Symposium Syriacum VII (OCA, 256; Rome: PIOS, 1998) 359-71.-The biographical information given by Schmidt (1996) 303-6 for the Syriac translator consists of a conflation of the data pertaining to our Joshua (Yeshue) and those pertaining to the physician 'Îsâ of Edessa, who was active in Melitene and then at the Cilician court and who, some time around 1244, financed the building of the church of Mar Barșawma in Sis (Chron. [Bruns-Kirsch] 505.11-3, [Bedjan] 479.5-8, [Çiçek] 433b 1723; Chron. eccl. I.669.21; cf. Honigmann [1954] 45; Fiey [1975a] 8 n. 30).Cf. n. 91 below.-While the evidence available is a little too meagre for a definitive identification of the Syriac translator of Michael's Chronicle, variously called Ishôh, Ishôhan etc. in the manuscripts (see Schmidt [1996] 304f. n. 29), with Joshua of Hesnâ d-Kêphâ, the statement that the translation was made in Hromkla (Qal'a Rumaita) rather than Sis and that the original Syriac text of the Chronicle had been made available to the translators by Patriarch Ignatius [III David], when we remember Joshua's associations with that patriarch, would seem to speak in favour of such an identification (see V. Langlois, Chronique de Michel le Grand, patriarche des syriens jacobites, traduite pour la première fois sur la version arménienne du prêtre Ischôk [Venice: l'Académie de Saint-Lazare, 1868] 10; cf. n. 88 below).See further para. [40]-[41] below. 


\begin{abstract}
"At that time [i.e. in 1266], Gregory of Melitene, alias bishop Simeon, the brother of the Patriarch, died. The priests [benun qashishe] demanded that the Patriarch consecrate the son of their brother, a small child not yet capable of reason, for Melitene [tr. Abbeloos-Lamy: Tum presbyteri illi a patriarcha poposcerunt ut Melitinae ordinaret suum e fratre nepotem, nomine Nemrod, puerulum discretionis nondum capacem]. The patriarch, however, giving his young age as the reason, refused to consecrate him, but assigned Melitene to the bishop of Qlisura, and for this reason [there arose] much strife between the Patriarch and the priests."
\end{abstract}

Kawerau, either looking only at the Latin translation and understanding "suum" as referring back to the "patriarch" or understanding the suffix of "abu-bun" as referring back to the patriarch and his brother Gregory Simeon, made Nemrod a nephew of Patriarch Ignatius IV Joshua. ${ }^{23}$ This misunderstanding then forced Kawerau to make Jacob, the abbot of Mar Barșawma, a brother of Ignatius IV, and, in order to account for a passage at Chron. eccl. II.455-7, ${ }^{24}$ to invent another brother of Ignatius IV, a physician called Rabban Simeon (!), and that despite the fact that Ignatius IV already has a brother called Gregory Simeon. ${ }^{25}$

Besides the awkward syntax and the problem of Ignatius IV having two brothers called Simeon, Kawerau's interpretation involves the problem that it is difficult to see how the patriarch's refusal to ordain his own nephew should have given rise to "much strife."

The suffix of "ahu-bun" must, in fact, refer back to "the priests." Who these priests were is not immediately obvious from the passage. An unfortunate mistake in the translation of

23 There is some mitigation for Kawerau's error in the fact the great J.S. Assemani, too, had earlier fallen into the same error in his paraphrase of this passage: "Per idem tempus obiit Gregorius qui et Simeon Melitinae episcopus, Patriarchae frater: cuius loco ut Nemrod eius [sc. Gregorii Simeonis] ex fratre nepotem ordinaret, Presbyteri eius Ecclesiae [i.e. presbyteri Melitinenses] Patriarcham rogarunt" (Assemani, B.O. II.381).

${ }^{24}$ Quoted under para. [12] below.

${ }^{25}$ Kawerau (1960) 72, 121. 
Abbeloos-Lamy a few lines later suggests that the local clergy in Melitene are meant. ${ }^{26}$

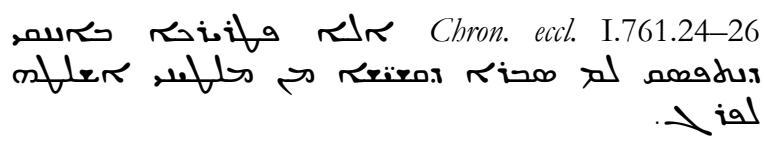

"at vero patriarcha ut spe dejiceret presbyteros Melitenenses, Pharagum etsi reluctantem praefecit" (my italics).

We need here rather to read: .".. in order that the hope of the priests might be cut off from Melitene ...," i.e. so that the priests would give up the hope of installing Nemrod in Melitene.

"The priests" must, in fact, be the priestly brothers Simeon and Jacob b. Joshua of Qale a Rumaita, between whom and the patriarch there was an ongoing quarrel, and who are referred to some lines later at Chron. eccl. I.763.6 as "the priests of Qal'a Rumaita" (qashishe d-Qal'a Rumoito).

The following passages of Chron. eccl., taken together, ought to provide sufficient proof for this point.

I.769.27f.: "the deacon Nemrod, the son of the brother of Rabban Simeon"

I.771.2-7: "With his [Bar 'Ebroyo's] consent, (the Patriarch) deposed Faraj from Melitene and consecrated Nemrod as the Metropolitan of Melitene in the Monastery of Gawikat on Sunday 1st Teshrin I 1585 A.Gr. [Oct. 1273], calling him Philoxenus. The Maphrian took him, brought him to Melitene and carried out the enthronement...

I.773.5-8: "In those days, Rabban Jacob, the abbot of Mar Barșawma, fearing for (the safety of) the son of his brother, the bishop Philoxenus of Melitene, ...”

I.779.4-15: "Then, Jacob, the priest, of Qal'a Rumaita, ${ }^{27}$... summoned to the Monastery of Mar Barșawma three bishops ... and forced them to

${ }^{26}$ Same error in Assemani, see n. 23 above.

27 I.e. "the priest Jacob, native of Qal'a Rumaita," not "Jacobus, Castri Romani presbyter," "Jakob, Presbyter in Qal'a Rumaita," as Abbeloos-Lamy and Kawerau (1960) 72 translate the phrase. 
consecrate the son of his brother, Philoxenus of Melitene, alias Nemrod, as the Patriarch in 1574 A.Gr. [1283], on the feast of the Entry [Presentation] of Our Lord in the Temple."

II.455.19-22, 457.7-11 [after Bar 'Ebroyo's refusal to receive the delegation from the newly-elected Patriarch Philoxenus Nemrod]: "Later, Rabban Simeon, the physician, came to the Maphrian in person and tried to persuade him with many (words) to accept $[\text { nqabliw (hy) }]^{28}$ the son of his brother ... While (the Maphrian) was on his way [to Nineveh], Taj al-Daula, the son of Rabban Simeon, came to him concerning the same matter. Because the Maphrian had educated and taught him, and loved him as (his own) son, he received him [qableb] and the gifts (he had) with him."

The recognition that Patriarch Philoxenus Nemrod was Simeon's nephew serves to underline the influence those with connections to the civil powers could exercise on the affairs of the Syriac Orthodox Church, for it was no doubt through Simeon's influence at the Ilkhanid court that Jacob was able to force through the election of his nephew to the highest office in the church despite the fact that the election had been held hastily under irregular circumstances, ${ }^{29}$ just as it must have been through

28 It seems that the verb "qabel" here has been understood in the sense of "receive, meet" (see, e.g., the English translation of the passage at Budge [1932] xxvi.7), allowing the interpretation that Simeon's nephew was a member of the delegation from Philoxenus. Although "qabel" at II.457.11 (with ref. to Taj al-Daula) must have that sense, "qabel" here needs to be taken to mean "accept [the election to the patriarchate of]."

29 The first thing Jacob did after the consecration of Philoxenus Nemrod was indeed to contact the Mongol noyan in the vicinity; together with a messenger from the noyan, Jacob then travelled to the khan's residence at Alațaq to obtain the latter's recognition (Chron. eccl. I.779.1521).- On Alâtâq, Ala-Dag, to the north of Lake Van, a favoured summer residence of the Il-khans, see F.W. Cleaves, "The Mongolian Names and Terms in the History of the Nation of the Archers by Grigor of Akanc'," HJAS 12 (1949) 400-443, here 404; Honigmann (1954) 73 n. 3; Gusejnov (1960) 160 n. 315; Spuler (1985) 278 n. 1 et passim.-I.779.15 smgrnwyn ed. Abbeloos-Lamy; swngr nuyn ms. Bodl. Hunt. 1, 607c 18: perhaps the same name (not same person) as that rendered shwmgr at Chron. [Bedjan] 491.10 
Simeon's influence that Simeon and Jacob had been able earlier to assert themselves in their quarrel with Patriarch Ignatius IV Joshua.

It might be remembered here that Ignatius IV, for his part, had close connections with the Armenian rulers in Cilicia. ${ }^{30} \mathrm{He}$ had, in the first place, been the abbot of Gawikat in Cilicia and it was in Cilicia that he was elected to the patiarchate, one of the grounds for his election evidently being the favour in which he was held by "the king and his magnates." 31 On one occasion in the conflict over the Monastery of Mar Barșawma, it was through Prince Lewon, the son of Het'um I (1226-70), who was visiting the khan at the time (in July 1269), that Ignatius obtained the yarlik granting him the possession of the monastery. ${ }^{32}$ A little later in 1272, when Prince T'oros (future T'oros III 1294-99), the son of the same Lewon (now King Lewon III, 1270-89), was baptised, it was, as we learn from an Armenian chronicle, not the Armenian catholicos but the Syrian patriarch who officiated at the ceremony. ${ }^{33}$

Such close connections with the civil powers were not to bode well for the fortunes of the Syriac Orthodox Church. As we know

(arabice/persice "Jûmghâr," "Jûmqûr," Mukhtasar târîkh al-dunval [ed. 1958] 263.15; Rashîd al-Dîn, ed. E. Quatremère, Histoire des mongols de la Perse écrite en persan par Raschid-Eldin, t. premier [Paris: Imprimerie royale, 1836] 98.9 with n. 24; Boyle [1958] 611 n. 20; Spuler [1985] 220).-At Chron. eccl. I.779.15f., instead of "et reliqua pro libitu suo inique perfecerunt," we should probably read "... r riv ...," "they explained the matter to him [to the noyan] as it suited them."

${ }^{30}$ Ignatius IV's two immediate predecessors, Ignatius III David and John b. Maedani, too, had close links with the Cilicians and resided for much of the time in their territory.-E. Ter-Minassiantz, Die armenische Kirche in ibren Beqiebungen zu den syrischen Kirchen bis zum Ende des 13. Jahrbunderts (TU NF 11/3; Leipzig: Hinrich, 1904) 132, would see in the developments around this time an attempt on the part of Armenians to make the Syriac Orthodox dependent upon them.

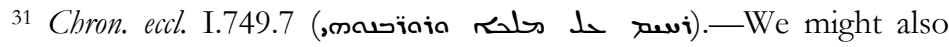
note in this connection Bar 'Ebroyo's designation of Ignatius and his supporters as "honun da-b-Qiliqiya" (Chron. eccl. I.753.21f., 24).

${ }^{32}$ Chron. eccl. I.765.1-10.-For the date of Lewon's visit to the khan, see Chron. [Bruns-Kirsch] 547.5-7, [Bedjan] 526.7-9, [Çiçek] 476a 1-4.

33 G. Dédéyan, La chronique attribuée au Connétable Smbat, DRHC 13 (Paris: Geuthner, 1980), 125. 
little about Philoxenus' patriarchate, ${ }^{34}$ we do not know how Simeon's fall in 1289 affected his position, but the effect could only have been adverse. A little later, as often in the history of the church, this dependence on the civil powers became a major factor in the schism which followed Philoxenus' death in 1292 and which contributed to the weakening of the church in this troubled period; of the three claimants Ignatius/Michael Barșawma, the abbot of Gawikat (ob. 1312), ${ }^{35}$ had the support of the "Armenian king," as well as of the "Mongols and Greeks in many places," 36 while Badr Zâkê Bar Wahîb of Mardin (1293-1333) ${ }^{37}$ turned to Malik alManșûr of Mardin for support ${ }^{38}$ and the short-lived Constantine attempted, at any rate, to win the support of "the rulers (abide)," presumably the Seljuks in Melitene. ${ }^{39}$

\section{SIMEON AND BAR ${ }^{e}$ EBROYO}

[16] Bar ${ }^{e}$ Ebroyo tells us in his Chron. that when Aleppo was taken by the Mongols in January 1260, he went to Hulagu's camp to entreat, in vain as it turned out, for the safety of his flock and was detained by the Mongols in Qal'a Najm. ${ }^{40}$ Bar ${ }^{e}$ Ebroyo then does not tell us anything about his own whereabouts between this date and 1263, when, upon the death of Patriarch John b. Ma danî, we find him at the Ilkhanid court (camp, ordu), ${ }^{41}$ in the capacity of a physician in

34 Cf. para. [30] below.-We do have a list of fifteen bishops ordained by Philoxenus in ms. Cantab. Dd $3.8^{2}$ (cf. n. 13 above; Barșaum [1964] 165, 351 init.; id., Lu'lu’ 135, no. 28).

35 Cf. Barșaum, Lu'lu’ 437, no. 242; cf. also ibid. 135, no. 30.

36 Chron. eccl. I.783.4f.

${ }^{37}$ Cf. Barșaum, Lu'lu’ 437f., no. 244.

38 Chron. eccl. I.785.17-24, II.495.20-26.-Malik al-Manșûr: the Artuqid (Ortoqid) Najm al-Dîn Ghâzî II al-Manșûr, 1294-1312 (Honigmann [1954] 74 n. 1).

${ }^{39}$ Chron. eccl. I.785.8-12, cf. Honigmann (1954) 74, 174.

40 Chron. [Bruns-Kirsch] 533.6-8, [Bedjan] 510.14-7, [Çiçek] 461b. 4-9.-Qalea Najm/Qal'at al-Najm has been identified with Gishrâ/Jisr Manbij, on the Euphrates to the east of Mabbug/Manbij (Honigmann [1954] 124).

41 An overview of the places where the nomadic Il-khans resided is given at Spuler (1985) 278-80. 
Hulagu's service and in the company of the priest-physician Simeon. ${ }^{42}$

Koffler has put forward the view that Bar ${ }^{\mathrm{e}}$ Ebroyo had spent much of this intervening period at the Mongol court in Maragha and that perhaps in the household of Simeon. The evidence adduced by Koffler is inconclusive, since his argument rests mainly on Bar 'Ebroyo's statement that it was in Maragha that he met some of the informants for his report of the events in 1260,43 but this does not imply that Bar ${ }^{\mathrm{e}}$ Ebroyo was in Maragha for the whole of the period from 1260 to 1263 , nor need it be before 1263 that he met these informants. ${ }^{44}$ Furthermore, Koffler's assertion that it

${ }^{42}$ Chron. eccl. I.746.ult.-747.6.

${ }^{43}$ Koffler (1932) 38f.-Of the passages cited there by Koffler, Chron. p. 556 (tr. Bruns-Kirsch) = ed. Bedjan 511.15-9 (corr. tr. Budge p. 437, where there is a glaring error in the translation of the phrase b-ordu, "in the Ordu," which Budge turns into a personal name, "AArdû").-Historia dynastiarum (Mukhtașar târîkh al-duwal), p. 350 (tr. Pococke) = ed. A. Șâlhâânî, Târikkh mukhtașar al-duwal li-l- 'allâma Ghrîghûriyûs al-malatî al-ma'rûf bi-'Ibn al-'Ibrî (Beirut: al-Mațba'a al-Kâthûlîkîya, 19582) 280.23-281.13; K. alManșûr, Târîkh mukhtașar al-duwal ta'lîf al allâma Abî al-Faraj Ghrîghûrìûs b. Abrûn al-Malatî al-ma rûf bi-'Tbn al-'Tbrî al-mutawaffâ sana 685 h. (Beirut: Dâr al-Kutub al-'Ilmîya, 1997) 245 (corresponding passage in Chron. at ed. Bedjan 513.3-22). The astronomer-informant mentioned without name by Koffler is none other than Muhyi al-Dîn [Yahyâ b. Muhammad b. Abî al-Shukr] al-Maghribî, who is mentioned again by Bar ${ }^{e}$ Ebroyo at ed. Beirut 1958, 287.7 and who, according to Hâjjî Khalîfa, composed an epitome of the Almagest at Bar 'Ebroyo's behest (Hâjjî Khalîfa, Kashf alzunûn, ed. G. Flügel, Lexicon bibliographicum et encyclopaedicum a Mustafa ben Abdallah Katib Jelebi dicto nomine Haji Khalfa celebrato compositum [Leipzig/London: Oriental Translation Fund, 1935-58, rep. New York/London: Johnson Reprint Corporation, 1964] V. 387, 389; cf. Suter, Die Mathematiker und Astronomen der Araber und ibre Werke [Leipzig: Teubner, 1900, rep. Amsterdam: APA Oriental Press, 1981] 155; C. Brockelmann, Geschichte der arabischen Literatur, 2nd ed. [Leiden: Brill, 1943, rep. ibid. 1996], I.474, Suppl. [ibid. 1937-42, rep. ibid. 1996], I.868f., F. Sezgin, Geschichte des arabischen Schrifttums [Leiden: Brill, 1967-84, Frankfurt: IGAIW, 1995-2000] V.114, 141, 155, 163, 187, 401, VI.292).

44 A better argument perhaps than Koffler's would be the relatively detailed knowledge Bar "Ebroyo shows of the reactions of the Mongol authorities to the series of events surrounding Dionysius 'Angur's 
was during this period that Bar ${ }^{~} E$ Ebroyo wrote the Mnorat qudshe (Candelabrum sanctuarii), $K$. d-zalge ( $L$. radiorum) and $K$. d-budoye (Nomocanon) must now be rejected. ${ }^{45}$

assassination in 1261 (Chron. eccl. I.729-741), but for this, too, Bar ${ }^{\text {E Ebroyo }}$ need not have been an eye-witness.

${ }^{45}$ Koffler's dating of these three works to 1260-4 (Koffler [1932] 33ff.) rested on Nallino's argument that the Hudoye, in which the other two works are mentioned (Hudoye VII.9, ed. P. Bedjan, Nomocanon Gregorii Barhebraei [Paris/Leipzig: Harrassowitz, 1898], 106.10f.; ed. J.Y. Çiçek, Nomocanon of Bar-Hebraeus [Glane/Losser: Bar Hebraeus Verlag, 1986], 64a.4f.; cf. Assemani, B.O. II.303a), was written before Bar 'Ebroyo's elevation to the maphrianate (C.A. Nallino, "Il diritto musulmano nel Nomocanone siriaco cristiano di Barhebreo," RSO 9 [1922/3]: 512-80, here 524f.; = id., Raccolta di scritti editi e inediti IV [Rome: Istituto per l'Oriente, 1942] 227-9; cf. also Vööbus [1970] 506f.). This argument of Nallino's, however, has been invalidated by Teule, Gregory Barbebraeus. Ethicon (Mêmrâ I) (CSCO, 534-5, syr. 218-9; Louvain: Peeters, 1993), versio $80 \mathrm{n}$. 45. The date of composition of the Mnorat qudshe, most probably the earliest of the three, must, in fact, be placed in the late 1260 's and early 1270's in view of the reference to 1575 A.Gr. (1263/4) as "three years ago" in Base II (II.3.4.3, ed. J. Bakos, Le Candélabre des sanctuaires de Grégoire Aboulfaradj dit Barbebraeus (PO, 22/4, 24/3; Paris: Firmin-Didot 1930-3] 221.6-8; ed. J.Y. Çiçek, Mnorath kudshe (Lamp of the Sanctuary) by Mor Gregorios Yohanna Bar Ebryoyo [Glane/Losser: Bar Hebraeus Verlag, 1997] 140.30-33; cf. Bakos, op. cit. 222 n. 1; also F. Nau, "La cosmographie au VII siècle chez les Syriens," ROC 15 [1910]: 225-54, here 246, 247 n. 2) and the period of "approximately 1274 years" since the birth of Christ mentioned in Base IV (IV.3.1.1, ed. J. Khoury, Le candélabre du sanctuaire de Grégoire Abou'lfaradj dit Barbebraeus. Quatrième base: de l'Incarnation [PO, 31/1; Paris: Firmin-Didot, 1964] 40.1f.; ed. Çiçek, 315.24-6; cf. Khoury, op. cit., intro. 7f; id., "Une synthèse de christologie jacobite: la 'quatrième base' du 'Candélabre des sanctuaires' de Grégoire Aboulfaradj dit Barhebraeus," Diss. Institut Catholique de Paris [unpublished], I.24f.); the latter passage indicates that this part was probably written, not in 1274 as Khoury supposed, but in 1271/2, since Bar 'Ebroyo elsewhere places Christ's birth in 309 A.Gr. (Chron. [BrunsKirsch] 50.3, [Bedjan] 45.20, [Çiçek] 38b 3f.; Awșar roze, chronological tables, ed. Zolinski, Zur Chronographie des Gregorius Abulpharagius, Diss. Heidelberg [Breslau 1894], Table IV 1. 64; cf. L. Bernhard, Die Chronologie 
[18] Nevertheless, the likelihood remains that Bar 'Ebroyo had spent at least some of the time between 1260 and 1263 in Maragha, and he may have been helped in establishing his position there through the contacts he already had at the Ilkhanid court.

It has been suggested by some that Bar ${ }^{\mathrm{e}}$ Ebroyo may have had contacts among the Mongols going back to the time when his father Aaron treated the Mongol general (noyan) Yasa'ur who had fallen ill while attacking Melitene in 641 A.H. (1243/4). ${ }^{46}$ Although Yasa'ur may still have been around in the 1260's, since he was still alive and stood under Hulagu's command as late, at least, as summer 1256,47 it seems unlikely that Bar ${ }^{~}$ Ebroyo could have expected any protection from him, seeing that Aaron, who had actually treated him, received no protection and remained in hiding when Yasa'ur attacked the region around Melitene for the second time in the summer of 1252.48

der syrischen Handschriften [VOHD Suppl., 14; Wiesbaden: Steiner, 1971] 129f.).

46 Bar 'Ebroyo, Mukhtașar târîkh al-duwal [Beirut 1958], 255.8-10, [Beirut 1997] 223.20-22 (= Assemani, B.O. II.245a 10-15; see also Bar 'Ebroyo, Chron. [Bruns-Kirsch] 504.18-505.11, [Bedjan] 478.13-479.5, [Çiçek] 433a 12-b 17).- -On the name Yasa'ur noyan, rendered 'Saurnavinus' by Assemani, see J.A. Boyle, The History of the WorldConqueror by 'Ala-ad-Din 'Ata-Malik Juvaini (Manchester: Manchester University Press, 1958) 46 n. 13; F. Sümer, "Anadolu'da Mogollar," Selcuklu Arastirmalari Dergisi (Ankara) 1 (1970): 1-147, here 1, 31, 142; Fiey [1975a] 8 n. 29.

47 Juwainî, Târîkh-i jahân-gushâi, tr. J.A. Boyle (1958) 712-4; Vardan Arewel'ci, Hawak'umn patmut'ean $\$ 90$, tr. R. Thomson, “The Historical Compilation of Vardan Arewelc'i," DOP 43 (1989): 125-226, here 217; cf. Boyle, "Kirakos of Ganjak on the Mongols," CAsJ 8 (1963): 199-214, here 211 n. 95; id., "Some Additional Notes on the Mongolian Names in the History of the Nation of Archers," in L. Ligeti (ed.), Researches in Altaic Languages (BOH, 20; Budapest: Akad. Kiadó, 1975) 33-42, here 34f.

${ }_{48}$ Chron. [Bruns-Kirsch] 517.7-10, [Bedjan] 492.15-20, [Çiçek] 445b 10-20.- Here again an infelicity in Budge's translation suggests that Yasa'ur's campaign took place not in 1252 but in 1255, and this has led to errors of dating in Boyle, "Kirakos" 211 n. 95, id. (1975) 35, Fiey (1975a) 17 and Fiey (1993) 202. The sentence mentioning the date 653 A.H. $(1255 / 6)$ at ed. Bedjan 491.18f. must be understood as being in parenthesis and the phrase "in the same year" at 491.19 understood as 
A contact Bar ${ }^{\mathrm{e} E b r o y o}$ would have had from a more recent past is with the fellow-Melitenite physician Qir Michael b. Gabras. ${ }^{49}$ It was through Qir Michael that Patriarch Dionysius 'Angur had obtained the recognition of the Mongols on his accession $^{50}$ and it was with Qir Michael, who was on embassy from the Ilkhanid court, that Bar ${ }^{~}$ Ebroyo travelled to the Ayyubid court in Damascus in 1258 to petition for his own and Dionysius' reinstatement, respectively, to the see of Aleppo and to the patriarchate. ${ }^{51}$

When we meet Bar ${ }^{~} E b r o y o$ at the Mongol court in 1263, however, it is not in the company of Qir Michael that we find him, but, as we have seen, in that of Simeon, who had himself entered Hulagu's service in or around $1260 .{ }^{52}$ There at the court, the two men were approached by an aspirant to the patriarchal throne, Theodore of Quplida. ${ }^{53}$ The way in which Simeon then confides to Bar ${ }^{e} E$ broyo his disapproval of the would-be patriarch and tells Bar 'Ebroyo to inform him of the outcome of the synod in Cilicia before the installation of the new patriarch suggests that Bar 'Ebroyo and Simeon had already known each other for some time

referring back to 650 A.H. (Mar. 1252-Feb. 1253) given at 490.25, in view of the reference, at 491.21, to the previous campaign of Yasa'ur, which had taken place in 641 A.H. $=1243 / 4$, as being eight years earlier and in view of the fact that this second campaign coincided with the patriarchal election of Dionysius 'Angur, which we know from Chron. eccl. I.698-701 to have taken place in Sept. 1252.

${ }^{49}$ Pace Kawerau (1960) 51, Michael was presumably Greek, rather than Syriac Orthodox by religion, as the title qir (< Gk. kyrios) suggests (cf. Chron. [Bedjan] 429.4, 501.22, Payne Smith, Thesaurus syriacus col. 3611, s.v.). Cahen suggests that he may have been a member of the family of Gavras (Taronites), who were prominent in Trebizond and some of whom had entered the service of the Rum Seljuks (C. Cahen, "Une famille byzantine au service des Seljuqides d'Asie-Mineure," in P. Wirth (ed.), Polychronion. Festschrift F. Dölger zum 75. Geburtstag [Heidelberg: Winter, 1966] 145-9, here 148).

${ }^{50}$ Chron. eccl. I.717.18-20.

${ }^{51}$ Chron. eccl. I.727.13-26; cf. II.427.14-7 (cf. Koffler [1932] 37; Kawerau [1960] 51).

${ }^{52}$ See the passage quoted under para. [3] above.

${ }^{53}$ Chron. eccl. I.747.3ff. 
and that Simeon already saw Bar ${ }^{\mathrm{e}}$ Ebroyo as his confidant at this stage. ${ }^{54}$

[22] While the elections of Ignatius IV Joshua and Bar ${ }^{e}$ Ebroyo to the patriarchate and to the maphrianate were taking place in Cilicia (Jan. 1264), Simeon's brother, Jacob, was approached by Theodore of Quplida in Qale a Rumaita and went to Cilicia in an attempt to annul the election of Ignatius IV. Having failed in his attempt, Jacob then travelled with Theodore and a group of rebel bishops to the Ilkhanid court. There, however, they were outmanoeuvred by Ignatius IV and his "Cilician party," who succeeded in winning royal recognition, largely, according to his own report, through the work of Bar ${ }^{\mathrm{e}}$ Ebroyo. ${ }^{55}$

Bar ${ }^{e}$ Ebroyo does not tell us what role Simeon had to play in this affair and it is, in fact, surprising that Jacob failed to gain access to the khan despite his brother's influential position at the court. It would seem either that Simeon felt bound by his obligation to Bar 'Ebroyo, or that Jacob's persuasion was not enough to reverse his brother's earlier negative opinion of Theodore. ${ }^{56}$

Whatever Simeon's attitude to Ignatius IV was at the beginning, it was not long before he was in open conflict with him, since the rebel bishops of Hesnâ d-Zaid ${ }^{57}$ and Claudia, when caught up by the patriarch, excused themselves by saying that they had been forced into what they did by "Rabban Simeon and his brothers," 58 and the conflict over the control of the Monastery of

${ }^{54}$ Chron. eccl. I.747.17-22.

${ }^{55}$ Chron. eccl. I.751-7.

56 Theodore was, in fact, abandoned a little later by Simeon and Jacob, supposedly on account of his unpopularity with the masses (Chron. eccl. I.757.24-7). Theodore then went over to the side of the patriarch (I.761.26ff.) and was entrusted with the Monastery of Mar Barșawma, but was immediately ejected by the Simeonians and retired to the Monastery of Shîrâ (I.767.9-28, cf. n. 15 above), a monastery probably located at the confluence of the Siro Çayi with the Euphrates, downstream of Melitene (Honigmann [1954] 82).

${ }^{57}$ I.e. Dioscorus Theodore of Hesnâ d-Zaid (Hisn Ziyâd/Harput), who had been proclaimed maphrian by the schismatic party (Chron. eccl. I.757.19-24; cf. I.753.2; Barșaum Lu'lu', 411; Fiey [1993] 216).

${ }^{58}$ Chron. eccl. I.759.12-4. 
Mar Barșawma, as well as over the episcopal appointment at Melitene, was soon in full swing. ${ }^{59}$

In his Chronicon ecclesiasticum, Bar ${ }^{\mathrm{E} E b r o y o}$ portrays his own position in this conflict as that of a neutral, concerned more with ending the conflict than supporting the claims of either party. ${ }^{60} \mathrm{In}$ his account of the conflict he appears equally critical of the litigiosity of both parties and, while there are some passages suggesting that he was if anything more sympathetic to the patriarch, ${ }^{61}$ it has to be remembered that this account was probably written some years after the end of the conflict and the reconciliation of the two parties. One suspects rather that there may have been some genuine ground for the patriarch's suspicion, reported by Bar 'Ebroyo himself, that he was on Simeon's side. ${ }^{62}$

The conflict ended, so to speak, in a legal victory for the Simeonians but in a moral victory for the patriarchal party, since some years after securing their legal rights to the monastery, the Simeonians, realising their unpopularity with the faithful, decided to reconcile themselves with the patriarch. ${ }^{63}$ Having made peace with the patriarch, Jacob comes to the Ilkhanid court to meet his brother and then to the city of Maragha to see Bar ${ }^{\circledR}$ Ebroyo. From there he returns with Bar ${ }^{\mathrm{e} E b r o y o}$ to the Monastery of Mar Barșawma and then to Cilicia. In Cilicia, the patriarch decides, in consultation with the maphrian, to depose Athanasius Faraj of

${ }^{59}$ Chron. eccl. I.759-69.

${ }^{60}$ Bar ${ }^{\mathrm{E}}$ Ebroyo makes no mention of his role in this conflict in Part I of his Chron. eccl., but in the account of his own maphrianate in Part II he tells us how, as he was on his way to the West in 1579 A.Gr. (1258/9), his path crossed with that of the patriarch who, for his part, was on his way to the Mongol court to bring a suit against Simeon. The maphrian did not wish to speak to the patriarch at first because he had earlier advised the patriarch against bringing such cases before the Mongols, which would only debase his own community in the eyes of the Mongols (Chron. eccl. II.439.17-441.13; see also II.441.21-5).

${ }^{61}$ See, for example, how Bar ${ }^{e}$ Ebroyo talks of "the patriarch, bishops and monks" resuming possession of the Monastery of Mar Barșawma "with great joy" (Chron. eccl. I.763.18f.).

${ }^{62}$ Chron. eccl. II.441.4f.

${ }^{63}$ Chron. eccl. I.769.1-12. 
Melitene and to consecrate in his place Nemrod, the nephew of Simeon and Jacob (1st Oct. 1273). ${ }^{64}$

It is interesting to see that it is Bar ${ }^{\mathrm{e}}$ Ebroyo who then carries out the enthronement ceremony in Melitene in contravention of the rule that the maphrian should have no jurisdiction in areas under the rule of the patriarch. ${ }^{65}$ It was no doubt the special circumstances of this ordination and the special relationship of the maphrian to the family of Simeon which led to the breaking of this rule, since we know from a passage already quoted under para. [12] above that Simeon's son Taj al-Daula was taught by Bar ${ }^{~} E^{2}$ broyo ${ }^{66}$ and it transpires from a passage occurring later on in Chron. eccl. that Nemrod himself was a disciple of Bar ${ }^{e}$ Ebroyo at one time. ${ }^{67}$

Bar 'Ebroyo's reaction to the election of Philoxenus Nemrod to the patriarchate in 1283 needs in particular to be seen in the light of his relationship to the family of Simeon. He refuses at first to recognise the election of Philoxenus, which was, as Bar ${ }^{e}$ Ebroyo stresses, carried out under irregular circumstances and forced through by the candidate's uncle, Jacob. Bar 'Ebroyo also rejects Simeon's approach on behalf of his nephew, but finally relents when approached by his former pupil and Philoxenus' cousin, Taj al-Daula b. Simeon. ${ }^{68}$ In a letter which he then wrote to the new patriarch and which he reproduced in his Chron. eccl., Bar ${ }^{\mathrm{e}}$ Ebroyo insists that he had had no ambition to become patriarch himself and that it was only the irregularities in the electoral procedure that he objected to. ${ }^{69}$

In the light of the associations between Bar ${ }^{e}$ Ebroyo and Simeon's family, it becomes all the more surprising that he should have opposed Philoxenus' election. Bar 'Ebroyo's very insistence in his letter that he had had no ambitions on the patriarchal throne, in

${ }^{64}$ Chron. eccl. I.769.13-771.9 (see under para. [12] above).

${ }^{65}$ On the rule, Kawerau (1960) 31 n. 204 (see also ibid., 32).

${ }^{66}$ Chron. eccl. II.457.7-11.

67 Chron. eccl. II.489.20-3 [in the continuation by Barșawma, recounting his own consecration as maphrian by Philoxenus Nemrod in 1289]: "because Mar Philoxenus, the patriarch there [i.e. Monastery of Mar Barșawma] had been his disciple [i.e. Barșawma's disciple] when he was in the service of the brother of this man [i.e. brother of Barșawma, = Barhebraeus maior], ...."

${ }^{68}$ Chron. eccl. II.455.14-457.11 (see under para. [12] above).

${ }^{69}$ Chron. eccl. II.457.13-459.22. 
fact, raises precisely the suspicion that he might have had such an ambition. ${ }^{70}$ Simeon, in particular, might have been expected after their long years of friendship to support Bar 'Ebroyo's candidacy, and perhaps it was because Bar Ebroyo felt betrayed by Simeon that he refused to accept his approach. Another factor behind Bar 'Ebroyo's initial refusal may have been his sense of alarm at the increasing influence and monopoly of Simeon's family over the affairs of the Syriac Orthodox Church.

How the relationship between Simeon and Bar ${ }^{\mathrm{e}}$ Ebroyo stood at the time of the latter's death in 1286 is difficult to assess, but it may be significant that neither Bar ${ }^{\mathrm{e}}$ Ebroyo nor his continuator (here most probably Bar 'Ebroyo's brother Barșawma) found anything to say about Philoxenus Nemrod's deeds in the part of Chron. eccl. dedicated to his patriarchate, the only event mentioned there being an earthquake which struck Melitene and the Monastery of Mar Barșawma, the residence of the patriarch, in $1596(1284 / 5)$ as a "chastisement" for "our follies."”1

${ }^{70}$ Bar ${ }^{e}$ Ebroyo tells us at Chron. eccl. I.777.1-10 of how Ignatius IV, sensing his approaching death, had written asking Bar 'Ebroyo to come him to "take care of him and of the (patriarchal) see" (cf. F. Schulthess, review article "Göttsberger, J., Barhebräus und seine Scholien zur Heiligen Schrift ...," GGA 164 [1902]: 161-8, here 162; W. Hage, "Gregorius Barhebräus," in M. Greschat [ed.], Gestalten der Kirchengeschichte IV [Stuttgart: Kohlhammer, 1983] 63-72, here 68).-We remember also that out of Philoxenus' four immediate predecessors in the patriarchate, two, Ignatius III David and John b. Maedani, had been raised to that dignity from the maphrianate (cf. Kawerau [1960] 19).

${ }^{71}$ Chron. eccl. I.779-81.- It might also be noted that the passage dealing with Simeon found at Chron. [Bedjan] 512.9-16 is suppressed at the corresponding place in the Mukhtașar târikh al-duwal (the passage would had its place between the sentences ending and beginning at ed. Beirut 1958, 280.17), but one need not attach much weight to this omission, as such omissions are common in the Mukhtasar. For discussions on the relationship between Chron. and Mukhtașar târikh alduwal, see the literature cited at Lane (1999) \$30-1 (Lüders, Conrad, Teule; of which Teule's analysis appears the most sound); to these one might add C. Colpe, "Bar Hebräus über die Manichäer," in E. Dassmann \& K.S. Frank (ed.), Pietas. Festschrift für Bernhard Kötting (JAC.E, 8; Münster: Aschendorff, 1980) 237-42, here 239, 241f., and among older literaturene pereant-P.J. Bruns, De rebus gestis Richardi Angliae regis in Palaestina. 
Simeon outlived Bar ${ }^{\mathrm{e}}$ Ebroyo by two and a half years, until he was executed together with other conspirators involved in the rebellion of Bogha (Bûqâ), the vizier of Arghun Khan, on 14th January $1289 .{ }^{72}$

The connection between the families of Bar ${ }^{e}$ Ebroyo and Simeon was continued when Philoxenus consecrated his former teacher and Bar 'Ebroyo's brother, Barșawma, as maphrian in 1289. ${ }^{73}$ In the Chron. eccl., at least, we hear nothing of Simeon's family subsequent to Philoxenus' death a little later in July $1292 .{ }^{74}$

Excerptum ex Gregorii Abulpharagii Chronico syriaco (Oxford: Fletcher, Prince \& Cooke / London: White \& Payne, 1780) 3; X. [= J.D. Michaelis?], review article "Gregorii Abulpharagii sive Bar Hebraei Chronicon Syriacum ... descripsit ... Paulus Iacob Bruns ... Georg. Guil. Kirsch ...," NOEB 7 (1790): 1-24, here 4-9; anonymous, "Der Uebergang der Oberherrschaft von den Ommaiaden auf die Abbasiden, nach dem syrischen und arabischen Texte des Abu-1-Faradsch zusammengestellt," Fundgruben des Orients (Vienna) 5 (1816): 346-50.

${ }^{72}$ Chron. [Bruns-Kirsch] 581.2f., [Bedjan] 563.5f., [Çiçek] 511a 811.- Here again Budge's translation (p. 480 init.), identifying Simeon with Abû al-Kiram of Arbil, is misleading (and misled Fiey [1975a] 51): "And on that day was killed also Shem'un, the priest, and physician, and lawyer, who was a Christian and a native of "Arbîl (now he was named "Abû al-

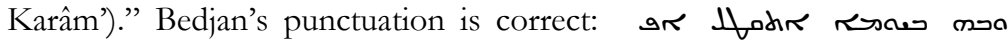

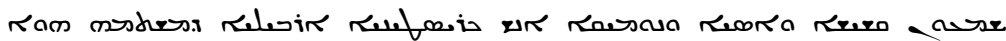
אתר את (recte, following Bedjan, tr. Armalet 50 [1956] 390.21f.). The confirmation for this and for the identification of the priest-physician Simeon here with Simeon of Qal a Rumaita is provided by Rashîd al-Dîn: “... u-Shimeûn maerûf bi-Rûm Qal'a u-Bahâ” al-Daula Abû al-Kiram nașrânî tamâmat râ bi-yâsâ rasânîdand" (K. Jahn, Târîh-i-Mubârak-i-Gâzânî des Rasîd al-Dîn Fadl Allahb Abî-l-Hair. Geschichte der Ilhâne Abâgâ bis Gaibâtû (1265-1295) [Prague, 1941, rep. The Hague: Mouton \& Co., 1957], 72.15f., cf. German summary p. 41f.; also J. von Hammer-Purgstall, Gescbichte der Ilchane [Darmstadt: Leske, 1842-3], I.380).- The date, Friday 14th Kanun II, is that given in the continuation of Chron.; Rashîd al-Dîn gives the date of Bogha's execution as 21st Dhu al-Hijja 687 (= Sun. 16th Jan.).

${ }^{73}$ Chron. eccl. II.489-91 (cf. n. 67 above).

${ }^{74}$ Chron. eccl. I.781.4-6. 


\section{SimEON AS BAR ${ }^{e}$ EBROYO'S LITERARY PATRON}

[33] So far we have been looking at what we may gather from Bar 'Ebroyo's historical works concerning the relationship between him and Simeon. These, however, are not the only places where Simeon is mentioned by Bar ${ }^{e}$ Ebroyo. In the prefaces of two of his works, Suloqo bawnonoyo (Ascensus mentis), a work on astronomy and mathematical geography, and $K$. d-remze wa-me ironwoto (L. indicationum et prognosticorum), the translation of Ibn Sina's K. al-Ishârât wa-ltanbîhât, Bar 'Ebroyo tells us that these works were written at the request of "Rabban Simeon, the king of the physicians of the king of kings of the world," specified further in $K$. d-remze as "the son of the late Rabban Joshua, the priest, of Qal'a Rumaita." 75

When we take these dedications together with our knowledge that Simeon's son Taj al-Daula and his nephew Nemrod were tutored by Bar ${ }^{\mathrm{e}}$ Ebroyo, ${ }^{76}$ it is not difficult to imagine that these two works, and perhaps some others, were written specifically for the education of the younger members of Simeon's family, along, perhaps, with a group of elite pupils around them, who were being groomed for high offices, be it ecclesiastical or, as had now become possible under the Mongols, political.

The intended readership of Bar 'Ebroyo's works and his intentions in composing his works are matters which have not so far been explored in any depth. Some of his works were no doubt intended for the education of the clergy and the two works of systematic theology, Mnorat qudshe and $K$. $d$-zalge, are indeed mentioned, albeit implicitly, as recommended readings in the

${ }^{75}$ For Suloqo hawnonoyo, see the edition of $\mathrm{F}$. Nau, Le livre de l'ascension de l'esprit (BEHE.E, 121; Paris: Firmin-Didot/Bouillon, 1899), text 2.3-6, tr. 1f. The superscription and preface of $K$. d-remze as found in ms. Mingana syr. 558 are reproduced in A. Mingana, The Catalogue of the Mingana Collection of Manuscripts, vol. I (Cambridge: Heffner, 1933), col. 1031f. The same passage is found in ms. Florence, Laur. or. 86 (no. 185 catal. S.E. Assemani), the codex veterrimus of $K$. d-remze copied in 1278, at fol. 1v 1-12, with the following variants: catal. Mingana col. 1032 line $1 d$ madnho d-hu Bar 'Ebroyo: om. Laur.; 1. 2 gurogo: pl. Laur.; 1. 3 nwghy': nwhgy' Laur.

${ }^{76}$ See para. [27] above. 
chapter on the priesthood in his $K$. d-budoye (Nomocanon). ${ }^{77}$ It is more difficult to see what use the ordinary clergy of his day had for those works of Bar ${ }^{e}$ Ebroyo dealing with the secular sciences, such as astronomy and natural philosophy. While there is evidence to show that Bar ${ }^{~} E b r o y o$ was interested in raising the general educational standard of his flock, ${ }^{78}$ the subjects dealt with in these works could only have been of interest to an elite group.

That there were specific people asking Bar ${ }^{e}$ Ebroyo to compose works on the secular sciences is, in fact, suggested by a sentence in the well-known, "autobiographical" passage at the beginning of Chapter 4 in the $K$. d-yawno (Liber columbae), ${ }^{79}$ where Bar ${ }^{e}$ Ebroyo tells us how, after he had become disillusioned with

77 Bar 'Ebroyo, Hudoye VII.9, [Bedjan] 105f., [Çiçek] 63-4 (cf. Assemani, B.O. II.302f., III/2.937-9, Vööbus [1970] 518-20), where after listing the canonical books of the Bible, Bar "Ebroyo gives us lists of patristic works "which are to be read in the Holy Church," followed by a list of secular works. The Mnorat qudshe and the Zalge are mentioned at ed. Bedjan 106.9-11, Çiçek 64a.1-5: "out of [Aristotle's] Auscultatio physica and Metaphysica, one is to take only as much as we have taken in our book, Mnorat qudshe, and the little book d-zalge."

${ }^{78}$ We see, for example, how, in the same chapter of the Hudoye as that cited in the preceding note, Bar ${ }^{\mathrm{E}}$ Ebroyo lays down rules concerning the educational system, enjoining bishops to appoint teachers as necessary, providing for the education of orphans and children of the poor and specifying the curriculum for use in the schools (Bedjan 107.9ult., Çiçek 64b.9-65a.2).

${ }^{79}$ K. d-yawno, ed. P. Bedjan, Liber columbae seu Directorium monachorum Gregorii Barhebraei (appended to id., Ethicon, seu Moralia Gregorii Barhebraet) (Paris/Leipzig: Harrassowitz, 1898) 577-9; ed. G. Cardahi, Abulfaragii Gregorii Bar-Hebraei Mafriani Orientis Kithâbhâ dhiyaunâ seu Liber columbae (Rome: Acad. Lincei, 1898) 75-8; ed. J. Y. Çiçek, Bar Hebraeus's Book of the Dove (Glane/Losser: Bar Hebraeus Verlag, 1983) 55-7; tr. A.J. Wensinck, Bar Hebraeus' Book of the Dove (Leiden: Brill, 1919) 60-2; tr. C. Alkan, Güvercin Kitabi (Glane/Losser, Bar Hebraeus Verlag, 1989) 49f.; Arabic version, ed. Y. Hubaiqa, "Kitâb al-ḥamâma li-Ibn al-'Tbrî," Machriq 50 (1956): 17-66, here 53f.-For discussions on the passage, see, among others, K. Samir, "Cheminement mystique d'Ibn al-'Ibrî (1226-1286)," POC 37 (1987): 71-89; K. Pinggéra, "Christologischer Konsens und kirchliche Identität. Beobachtungen zum Werk des Gregor Bar Hebraeus," OstKSt 49 (2000): 3-30, here 21-8. 
the "Greek" sciences, he continued to occupy himself with them "for the sake of those who wished to profit by me." 80 The prefaces of Suloqo hawnonoyo and K. d-remze allow us to identify at least oneand that probably the most important-of those people who "wished to profit" by Bar 'Ebroyo's knowledge.

While we have no positive indication that any of the other works of Bar ${ }^{e}$ Ebroyo besides the Suloqo and Remze were composed specifically at Simeon's request, the circumstances discussed above make it likely that we owe at least some of the other works to his encouragement.

The period during which Simeon acted in this way as literary patron for Bar 'Ebroyo may extend over the whole of Bar 'Ebroyo's maphrianate (1264-86)—during which almost all his works were in fact written - or may be limited to a certain period within those years. Of the two works explicitly dedicated to Simeon, Suloqo hawnonoyo is known to have been written in 1279,81 while for the date of the K. d-remze we have a terminus ante quem of December 1278, the date of the oldest manuscript, ${ }^{82}$ so that those works written around this time might be considered as being more likely than others to have been composed under Simeon's influence, but given the close association between Simeon and Bar 'Ebroyo throughout the latter's maphrianate, there is no need to limit the relationship discussed here to this period.

Those works which may have been composed under Simeon's encouragement will include the astronomical tables "for beginners" mentioned in lists of his works, ${ }^{83}$ along with the philosophical

${ }^{80}$ Ed. Bedjan 579.1-3, ed. Çiçek 56.12f.

${ }^{81}$ The date mentioned at ed. Nau 26.4f., 196.10f.

82 I.e. Laur. or. 86 (cf. n. 75 above), copied by John b. Bacchus of Bartelli, the copyist also of ms. Cantab. Add. 2003, the codex veterrimus of the Tegrat tegroto (1276 A.D.).

${ }^{83}$ Chron. eccl. II.479.4f.: "Ktobo rabo zîj l-sharwoye da-d-lo 'amlo napqun meneh taqwîm."- It has been suggested that the "kalendarium" (in Syriac) found sandwiched between the texts of Bar 'Ebroyo's Profession of faith and the "Laughable stories" in ms. Vat. syr. 173 (no. X) might be identified as this work J.S. Assemani, B.O. II.307; S.E. \& J.S. Assemani, Bibliothecae Apostolicae Vaticanae codicum manuscriptorum catalogus, part I, vol. III (Rome, 1759), 353; cf. Göttsberger [1900] 52; Baumstark, GSL 318 n. 2; contra: W. Wright, A Short History of Syriac Literature [London: Black, 1894] 271 n. 4).-The use, however, of Arabic terms $₹ \hat{\imath} j$ and taqwim 
works, of which Swod sufiya (Sermo sapientiae) and $K$. d-boboto (L. pupillarum) may have been written in the 1270 's ${ }^{84}$ and-here we remember the profession of Simeon as a physician-the medical works ${ }^{85}$ while the grammatical works would also come into

in the title suggests that this was an Arabic work and two early lists of Bar 'Ebroyo's works, in fact, state that this was the case (in mss. Vat. Borg. syr. 146 Scher $=$ no. 3 Perini, copied by 'Abd Allâh b. Barșawmâ of Bartelli probably in 1290/1, see D. Perini, "Catalogo dei codici manoscritti ed oggetti portati dall' Oriente nel 1879 dal P. Agostino Ciasca Agostiniano," Bess. ser. 2, 6 [1904]: 58-71, 258-81, here 62, cf. Barșaum, Lu'lu' 440; and Laur. or. $298=$ olim palat. $428=$ no. 62 catal. S.E. Assemani; the list in the latter is in the same hand as the text of Bar 'Ebroyo's metrical grammar copied by Daniel of Mardin in 1360; in the footnote at J.S. Assemani, B.O. II.267-9, which is taken from Laur 298, the word duraiz is printed in the Syriac text but omitted in the Latin translation; similarly at S.E. Assemani, Bibliothecae Mediceae Laurentianae et Palatinae codicum MSS orientalium catalogus [Florence 1742] 111 and appendix p. LI).

${ }^{84}$ Of the other philosophical works, there is some reason to believe that the Tegrat tegroto, which at any rate predates the Swod sufiya (see Swod sufiya, ed. H.F. Janssens, L'entretien de la sagesse, Introduction aux oewvres philosophiques de Bar Hebraeus [BFPUL, 75; Liège: Faculté de Philosophie et Lettres, 1937] 54.5, tr. 173) and May 1276, the date of ms. Cantab Add 2003 (Wright-Cook [1901] 495), was composed before Mnorat qudshe (Takahashi, "Barhebraeus und seine islamischen Quellen. Têgrat têgrâtâ und Gazâlîs Maqâșid al-falâsifa," paper presented at the 2. Symposium zu Geshichte, Theologie und Liturgie der syrischen Kirchen, Wittenberg, 14 16 July 2000; on the date of the Mnorat qudshe, see n. 45 above).-Hewat bekmto (Butyrum sapientiae), on the other hand, was written almost at the end of Bar 'Ebroyo's life in 1285/6 (so the colophons in mss. Mingana syr. 310, fol. 216r, and Laur. or. 83 [no. 187 catal. S.E. Assemani], fols. 191v, 227r; cf. D. Margoliouth, Analecta orientalia ad Poeticam Aristoteleam [London: Nutt, 1887, rep. Hildesheim: Olms, 2000] 41f.).

85 That Bar Ebroyo had disciples studying medicine under him during his maphrianate, we learn from his report that he arranged the marriage of two of his medical disciples, Abu al-Khair and John, and made them settle in Tabriz and Maragha in 1283 (Chron. eccl. II.459.23461.1). 
question, together with the Syriac Chronicle (Chron. and Chron. eccl.), a part, at least, of which was written in $1274 .{ }^{86}$

The last of these, of course, is the work in which we find the eulogy of Simeon quoted under para. [3] above. The likelihood that Simeon would have taken a particular interest in this work will be increased if his father Joshua was indeed one of those responsible for the Armenian version of Michael's Chronicle, ${ }^{87}$ the work used as the principal source in the earlier parts of Bar 'Ebroyo's Chronicle. 88

${ }^{86}$ The date mentioned at Chron. [Bruns-Kirsch] 41.4, [Bedjan] 37.18f., [Çiçek] 31b 3f. (cf. Göttsberger [1900] 40). Fiey would have Bar ${ }^{\circledR}$ Ebroyo completing the work during his stay in Maragha in 1272-3 (Fiey, "Âḍarbâygân chrétien," Muséon 86 [1973]: 397-435, here 432). Bar "Ebroyo no doubt continued updating this work until close to his death.

${ }^{87}$ See para. [6] above.

88 The Syriac text used as the basis for the Armenian version is believed to be Michael's autograph, made available by Patriarch Ignatius III David who frequently resided in and died in Qalea Rumaita/Hromkla (the text of the colophon of the Armenian version accessible to me, however, talks merely of the 'exemplar', which does not necessarily imply the autograph: “... mar Ignatiê Antiok'u, or z-ôrinaks shnorheac'," E. Dulaurier, "Extraits de la Chronique de Michel le syrien," JA 4 ér.r. 12 [1848]: 281-334; 13 [1849]: 315-76, here 12.286). This manuscript probably went back to the Monastery of Mar Barșawma upon Ignatius' death, since a "book of the Chronicle" was among the items bequeathed by the patriarch to that monastery (Chron. eccl. I.693.18; cf. Schmidt [1996] 305). For this reason it is sometimes said that Bar ${ }^{\circ}$ Ebroyo consulted Michael's Chronicle at the Monastery of Mar Barșawma (so, e.g., E. Tisserant, "Michel le syrian," DThC 10 [1929]: 1711-9, here col. 1716, specifying the date as 1255 , around which time Bar 'Ebroyo is known from Chron. eccl. I.728 to have been at the Monastery; and Schmidt, loc. cit., giving the date of 1276, which, however, is most unlikely as Bar EEbroyo was nowhere in the neighbourhood of Mar Barșawma in that year as far as we can make out from Bar 'Ebroyo's own account of his maphrianate in Chron. eccl. II.431-467). Given the extensive borrowings in his Chronicle from Michael's Chronicle, however, it would seem more likely that Bar ${ }^{~}$ Ebroyo had procured for his own use a copy—or perhaps the autograph itself_-of Michael's Chronicle, either through his own connections with the monastery or, perhaps, through Simeon, the son of Joshua, the translator, and the brother of Jacob, the abbot of Mar Barșawma. 
Simeon may also have been instrumental in securing for Bar EEbroyo the access to the library in Maragha, where, as he tells us in the preface to his Chronicle, Bar "Ebroyo found the "Syriac, Saracen and Persian" works he used in composing this work (and no doubt also in composing others), ${ }^{89}$ although for this purpose Bar 'Ebroyo's standing as a scholar in his own right might have sufficed. ${ }^{90}$

${ }^{89}$ Chron. [Bedjan] 2.10-13.-The library in question is undoubtedly that attached to the observatory in Maragha, where, according to one 14th c. account, some 400,000 volumes of books had been gathered from "Baghdad, al-Shâm and al-Jazîra" (al-Kutubî, Fawât al-wafayât, ed. M.M. 'Abd al-Hamîd [Cairo: Maktabat al-Nahḍat al-Mișriya, 1951] II.307.penult.-308.1; ed. I. 'Abbâs [Beirut: Dar Sader, 1974] III.247.2f.; cf. E. Wiedemann, "Zum Leben von Nașîr al Dîn al Țûș̣̂," Sitzungsberichte der physikalisch-medirinischen Sozietät zu Erlangen 58/59 (1926/7) 363-79, here 365f.).

${ }^{90}$ Bar 'Ebroyo's use of the library in Maragha and his contacts with the circle of scholars who had gathered there around Naṣîr al-Dîn al-Tûsî (1201-1274) are an important aspect of the background to Bar 'Ebroyo's literary activity, which is well worth exploring but which falls beyond the scope of the present article.-For Bar 'Ebroyo's eulogy of TTûsî, see Chron. [Bruns-Kirsch] 550.3-14, [Bedjan] 529.9-24, [Çiçek] 478b 18-479a 20 (at tr. Budge, 452.3, for "a lexigographical work in Persian," read "Ethica in the Persian language"), and Mukhtasar târikh al-duwal [Beirut, 1958] 286.penult.-287.5, [Beirut, 1997] 251.11-6 (followed by a list of scholars active at the time, some of them also in Maragha, ed. Beirut 1958, 287.510).- On Bar 'Ebroyo's use of Țûsîs Akblâq-i nâsirî̀ in his Hewat hekmto, see M. Zonta, Fonti greche e orientali dell' Economia di Bar-Hebraeus nell' opera "La crema della scienza" (AION.S, 70; Naples: Istituto Universitario Orientale, 1992) and id., "Structure and Sources of Bar-Hebraeus' 'Practical Philosophy' in The Cream of Wisdom," in R. Lavenant (ed.), Symposium Syriacum VII (OCA, 256; Rome: PIOS, 1998) 279-92.F. Nau's supposition (Nau [1899], tr. vii) that the Suloqo bawnonoyo is based on TTusî's Tadbkira fí 'ilm al-bay'a can now be confirmed through a comparison of the former with an edition of the latter, F.J. Ragep, Nasir al-Din Tûsî"s Memoir on Astronomy (al-Tadbkira fì ilm al-hay’a), 2 vols. (New York/Berlin/Heidelberg: Springer, 1994); cf. Takahashi, "The GrecoSyriac and Arabic Sources of Barhebraeus' Mineralogy and Meteorology in Candelabrum sanctuarii, Base II," paper presented at the VIII. Symposium Syriacum, Sydney, June 2000.—On a manuscript of Țûsî’s mathematical 
The connection, via Simeon, with his father Joshua could also have a bearing on the philosophical works, if, as has been suggested, Joshua or, armenice, Ishôh, the translator of Michael's Chronicle, may be identified further with the author of a popular Armenian work on natural philosophy, the Girk' $i$ veray bnut'ean. ${ }^{91}$

works apparently copied in part by Bar ${ }^{\mathrm{E}}$ Ebroyo and carrying his signature, see A. Sayili, "Khwâja Nașîr-i Țûsî wa rașadkhâna-i Marâgha," AÜDFD 14 (1956): no. 1-2, p. 1-12, here 10-12 and plate facing p. 16; and id., The Observatory in Islam and its Place in the General History of the Observatory (TTKY, VII/38a; Ankara: Türk Tarih Kurumu Basimevi, 19882) 219-22 (ms. Istanbul-Üsküdar, Haci Selim Aga Kütüphanesi, Selim Aga 743, with

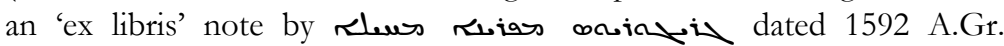
[1280/1] on fol. 138; on the contents of the older part of this manuscript, fols. 138-282, dated 671-8 h. [1272-80], see M. Krause, "Stambuler Handschriften islamischer Mathematiker," Quellen und Studien zur Geschichte der Mathematik, Astronomie und Pbysik, Abt. B, 3 [1936]: 437-532, here 499503).- On Bar ${ }^{\mathrm{e}}$ Ebroyo and Muhyi al-Dîn al-Maghribî, see n. 43 above.-

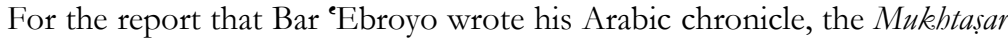
târikh al-duwal, at the request of the Arabs (Tayoye) in Maragha, see Chron. eccl. II.469.1-5, and for a discussion on this passage, L. Conrad, "On the Arabic Chronicle of Bar Hebraeus: His Aims and Audience," ParOr 19 (1994): 319-78, here 328-32 (cf. n. 71 above).-Cf. further Koffler (1932) 30f.; Teule (1993), versio xi.

${ }^{91}$ This is the view of the editor of the Girk' $i$ veray bnut'ean. See S.A. Vardanyan, Ișoch. Kniga o prirode (Erevan: Izd. Akademii Nauk Armjanskoj SSR, 1979) 6-8 (Russian), 55f. (Armenian), 106f. (English summary); cf. id. "Ancient Armenian Translations of the Works of Syrian Physicians," REArm NS 16 (1982): 213-9, here 216; and J.P. Mahé's review of Vardanyan's edition, REArm NS 14 (1980): 524f.—Vardanyan suggests an identification of the author/translator Ishôh further with 'Isa of Edessa (with circumspection in her Russian introduction, "the possibility cannot be excluded that ..."; with more confidence in Armenian, "in all probability ..."; with no such qualification in the English summary), evidently on no firmer ground than the fact that this was the only viable candidate she could find mentioned in $\underline{L}$. Alishan's work on Armenian Cilicia which he cites (Sisuan [Venice 1885], 554). Cf. n. 22 above.-Many of the subjects treated in the Girk' $i$ veray bnut'ean are also dealt with by Bar 'Ebroyo in his works, especially in Base II of his Mnorat qudshe and in his Hewat hekmto. These subjects, going back ultimately to Aristotelian, Ptolemaic and Galenic sources, are admittedly those 
The connection, via Simeon and Joshua, with the latter's collaborator, Vardan Arewelc'i (ob. 1271), an author, like Bar 'Ebroyo, of a history, a grammar and biblical commentaries, may also be worth exploring. ${ }^{92}$

frequently treated in the scientific literature of the period, but the thought presents itself that the inclusion of these themes in Bar 'Ebroyo's works may perhaps reflect Simeon's interest in them inherited from his father.

${ }_{92}$ On Vardan and his works, see Thomson (1989) 126-8.-There is a slight possibility that Bar ${ }^{~} E$ Ebroyo might have met Vardan when the latter visited Hulagu in July 1264 (Vardan, Hawak'umn patmut'ean \$96, tr. Thomson [1989] 220f.), since Bar 'Ebroyo, too, was in Hulagu's camp at one point in 1264, although it is rather more likely that he would have departed thence for Mosul by July (Chron. eccl. I.753.8-757.10, II.433.1519; cf. para. [22] above).-Like his contacts with the Muslim scholars in Maragha (cf. n. 90 above), Bar 'Ebroyo's possible contacts with Armenian scholars is a theme worth investigating.-Bar 'Ebroyo's disciple and biographer, Dioscorus Gabriel b. John of Barțelli (bishop of Gâzartâ dQardû) names Armenian, along with Syriac, Arabic and Persian, among the languages spoken by Bar 'Ebroyo J.Y. Çiçek, Mimro al qadisho Griguriyus mafryono d-madnho da-bid l-Diyusqurus episqupo d-Gozarto mdito dQardu shnat 1286 m. [Glane/Losser: Bar Hebraeus Verlag, 1985], 39.5-6; cf. A. Sauma, "Commentary on the 'Biography' of Bar Hebraeus," Aram [Stockholm] 7 [1998]: 35-68, here 40).-His knowledge of Armenian, on the other hand, was evidently not good enough for him to preach in that language, as we may gather from the report that when he preached in Sis on the occasion of his election to the maphrianate, his sermon was translated into Armenian by another, a certain Theodore Smaqrâyâ (Chron. eccl. I.749.8f., = Assemani, B.O. II.247).- Similarly Göttsberger was doubtful that the "Armenian" readings mentioned in the Awșar roze were taken directly from Armenian sources (Göttsberger, "Die syroarmenischen und die syro-koptischen Bibelcitate aus den Scholien des Barhebräus," $Z A W 21$ [1901]: 101-41, here 123-7; cf. id. [1900] 9f., 147f.).-Sbath's identification of Abû al-Faraj, who collaborated in the translation of a work on hippiatrics (Aqrâbâdbin fî ilm tibb al-khail) from Armenian into Arabic, with Bar ${ }^{\circ}$ Ebroyo has no foundation besides the coincidence of the name (P. Sbath, Al-Fibris [Cairo: Imprimerie Al-Chark, 1938-40], III.62 nos. 1202-2; id., "Manuscrit arabe sur la pharmacopée hippiatrique," Bulletin de l'Institut d'Égypte 14 [1931/2]: 79-81, here 81).On some items relating to Armenia in Chron., see H. Kurdian, "A Few Corrections in the English Translation and Transliteration of the 
One question which has to be addressed when dealing with Bar 'Ebroyo's works is the question as to why he wrote most of his works in Syriac.

It is needless to point out here that ample evidence for Bar 'Ebroyo's ability to write in Arabic is provided by his Arabic chronicle, the Mukhtasar târikh al-duwal, while most of his medical works, too, appear to have been written in Arabic. ${ }^{93}$ Rather more

Chronograpy of Gregory Abû'l Faraj (Bar Hebraeus)," JRAS (1938): 431.-Besides in 1264, Bar "Ebroyo was in Cilicia on at least two occasions during his maphrianate, in 1267/8, when he fell ill with dysentry there, and in 1273 (Chron. eccl. II.441.10-21, 443.25f.; in connection with the first visit, cf. Bar 'Ebroyo's poem reproaching a city in Cilicia for its bad grapes, A. Scebabi, Gregorii Bar-Hebraei Carmina [Rome: Typ. Polyglotta, 1877] 165.8-12, P.Y. Dolabani, Mushboto d-Mor Griguriyus Yuhanon Bar ${ }^{\circledR}$ Ebroyo mafryono d-madnhọo Jerusalem: Dair Mâr Marqûs, 1929, rep. Glane/Losser: Bar Hebraeus Verlag, 1983] 53f., no. 4.13).—Although there is no record of his visit to Greater Armenia in Chron. eccl., manuscripts of the Shorter Anaphora of St. James are reported to state that Bar "Ebroyo revised this anaphora "in the mountains of Greater Armenia in 1593 A.Gr. (1281/2)" (so Vat. syr. 34, 542/6, Paris. syr. 74/3, 81/10, 82/4, 111/14, 114/9, Cambridge, Selwyn College, syr. 2/4; with variations in wording, Jerusalem, St. Mark's 94/1, Cantab. Add. 2887/2, Mingana syr. 391I, 563B; see the respective manuscript catalogues of AssemaniAssemani, van Lantschoot, Zotenberg, Brock, Dolabani, Wright-Cook and Mingana, and A. Raes, "XV. Anaphora minor Sancti Iacobi, fratris Domini,” ASy 2/2 [Rome: PIOS: 1953]: 181-210, here 188).

${ }^{93}$ Of the eight medical works mentioned in lists of Bar 'Ebroyo's works, the one (partially) published work, the Muntakhab jâmi al-mufradât, is in Arabic (M. Meyerhoff-G.P. Sobhy, The Abridged Version of "The Book of Simple Drugs" of Ahmad Ibn Muhammad al-Ghâfiqî by Gregorius Abu'l-Farag (Barbebraeus) [Cairo: Government Press, 1932-40]).-Of the others, Henyon yutrone d-hadomay pagro, a work presumably based on Galen's De usu partium, and Pushoqo d-posuqe d-Ipuqratis, the commentary on Hippocrates' Aphorisms (which may be extant, see Barșaum, Lu'lu', 428, P.Y. Dolabani et al., "Catalogue des manuscrits de la bibliothèque du Patriarcat Syrien Orthodoxe à Homș (Auj. à Damas)," ParOr 19 [1994]: 555-661, here 589, no. 6.17), are stated to have been in Arabic.-The epitome of Hunain's Masâil fì al-tibb ( $K$. d-šsuole d-Hunain ba-psiqoto) is stated in some manuscripts of Cbron. eccl. to have been in Arabic and in others to have been in Syriac. A manuscript in Dublin whose content may be identified 
interestingly, if, as seems possible, one of his works on psychology, the Maqâla mukbtașara fì al-nafs al-bashariya (ed. L. Cheikho 1898), which, as noted by Graf, ${ }^{94}$ closely follows the work on the soul by Moses b. Kepha, ${ }^{95}$ may be identified with the Mimro shenoyo, which is mentioned in some lists of his works and which, for its part, must have been written at the latest before $1261,{ }^{96}$ this will mean

with this work is in Arabic (Chester Beatty arab. 4925, A.J. Arberry, The Chester Beatty Library. A Handlist of Arabic Manuscripts [Dublin, 1955-66], VI.144; pace Arberry there is no ground in the manuscript itself for the identification of the author with the maphrian Gregory who died in 1214; cf. also Dolabani et al. [1994], loc. cit.).- - The language of the other four works, the abridgement of De materia medica (K. d-Diyusquridis), the work on Ibn Sina's Qânûn fî al-tibb ( $K$. d-qonuno $d$-Abu ' $A l i$ ), the commentary on the Masâ'il fî al-tibb (K. d-pushoqo d-su'ole d-Hunain) and the K. $d$-kanesh beh kulbun réyone osyoye, is unknown.-Besides these eight works, a commentary in Arabic on Hippocrates' Prognosticon/Taqdimat al-ma rifa is attributed to Bar 'Ebroyo by Cheikho and Sbath (L. Cheikho, Kitâb al-makhtûțât al- 'earabîya likatabat al-nașrânŷya [Beirut, 1924], 10 fin.; P. Sbath, Al-Fibris I.15, no. 63; cf. Sezgin, GAS III.33; also Dolabani [1994], loc. cit.).

${ }_{94}$ G. Graf, Geschichte der christlichen arabischen Literatur (Vatican City: Bibl. Apost. Vaticana, 1944-51) II.273f.

${ }^{95}$ I.e. the work published in translation by O. Braun, Moses bar Kepha und sein Buch von der Seele (Freiburg: Herder, 1891); cf. Baumstark, GSL, 281 n. 7; J. Reller, Mose bar Kepha und seine Paulinenauslegung (GOF.S, 35; Wiesbaden: Harrassowitz, 1994) 66f.

96 The work is mentioned in the list of Bar 'Ebroyo's works in ms. Laur. or. 298 (olim 428; this part of manuscript copied in 1360, cf. n. 83 above), fol. 82r 4 (cf. J.S. Assemani, B.O. II.269, footnote, no. 28; pace Assemani there is no warrant for the vocalisation of the word as sinnoyo, the letter šn $^{\prime}$ being vocalised "e" in the manuscript). According to another list of Bar 'Ebroyo's works found in a manuscript of the Mnorat qudshe once in the possession of Patr. Ign. Ephrem Barșaum, this work was named ع

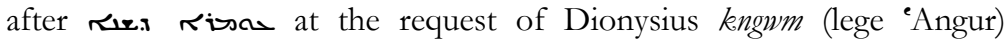
Shenoyo (see I.E. Barșaum, Risâla fî 'ilm al-nafs al-insânîyy li-l- allâma Mâr Ghrîghûriyûs Ibn al-ibrî mafriyân al-mashriq Jerusalem: Dair Mâr Marqûs, 1938], 2, and id., Lu'lu', 420, sub no. 8; on אerson as a byname of the Monastery of Mar Barșawma, see Honigmann [1954] 43f.). Barșaum identifies this عus ros with Mukbtașar fi 'ilm al-nafs al-insanîya (ed. P. Sbath, Cairo 1928; I.E. Barșaum, op. cit., Jerusalem 1938), but as noted by Furlani ("Barhebreo sull' anima razionale," Or. NS 1 [1932]: 1-23, 97- 
that Bar ${ }^{~}$ Ebroyo, who later composed many a Syriac work based on Arabic sources, may have begun his literary career with an Arabic work based on a Syriac source. ${ }^{97}$

It is not so surprising that those works intended for a clerical readership were written in Syriac, since there is some evidence to suggest that, despite the decline in the number of Syriac-speakers over the centuries, the Syriac Orthodox clergy (at least those in the "West") were not necessarily, or even usually, conversant in Arabic at this period. ${ }^{98}$ What requires some explanation is the reason as to why Bar ${ }^{e}$ Ebroyo should have composed his secular works (most of which are themselves based to a large extent on Arabic and Persian sources) in Syriac, especially if, as has been suggested, many of these were written at the request of persons like Simeon, who was surely quite as at home in Arabic and Persian as in Syriac.

The key to the answer as to why Bar ${ }^{~}$ Ebroyo composed his works in Syriac is no doubt to be sought in the political situation of the day. From the section division of his Chron., where he ends the long tenth section of the "Kings of the Arabs" with the fall of Baghdad and the death of the last Abbasid Caliph in 1258 and begins a new section dealing with the "Kings of the Huns" (i.e.

115, here 115; cf. Graf, GCAL, II.277), the Mukbtasar is largely an abridgement of the corresponding part of the Mnorat qudshe, which in turn was written around 1270 (see n. 45 above), well after the death of Dionysius "Angur in 1261, so that, if the rur riss is to be identified with one of Bar 'Ebroyo's two surviving Arabic treatises on the soul, the other, the Maqâla mukbtasara fì al-nafs al-bashariyyya, is the more likely candidate.

${ }^{97}$ The language of the Pushoq helme, on interpretation of dreams, said to have been composed by Bar ${ }^{~ E b r o y o ~ i n ~ h i s ~ y o u t h ~(C h r o n . ~ e c c l . ~}$ II.479.9f.), is unknown.

${ }^{98}$ See the mention in Chron. eccl. of the requirement of maphrians to be proficient in Arabic (II.333.21-ult., 337.9f., 411.16ff., with reference to maphrians Ignatius Lazarus, 1143-64, and John b. Maedani, 1232-53, cf. Kawerau [1960] 27; also I.699.7-9, John b. Madani) and the report that Bar 'Ebroyo acted as an interpreter between Patriarch Dionysius VII 'Angur and al-Malik al-Nâșir at the Ayyubid court in Damascus (I.717.10 12).-Cf. also Chron. [Bruns-Kirsch] 544.13-5, [Bedjan] 523.12-4, [Çiçek] 473a 20-4, where Bar ${ }^{\mathrm{E}}$ Ebroyo mentions the presence a monk who spoke Arabic at the monastery of Gawikat in Cilicia in a way which suggests that this was unusual. 
Mongols), we may infer that Bar ${ }^{\circ}$ Ebroyo saw the events of 1258 as marking the most important break in history since the Islamic conquests of the 7 th century. It is quite possible that Bar ${ }^{e}$ Ebroyo shared the hope of many of his fellow Christians that the new rulers would convert to Christianity-and there is some evidence that he did, for he compares Hulagu's mother, Sarqûtanî (Sorqoqtani, Seyurhohataitai), ${ }^{99}$ to Empress Helena in his Chron., thereby implicitly comparing Hulagu to Constantine ${ }^{100}$ — but this hope aside, there must have been a feeling in the early days of Ilkhanid rule that a new world order was being established, and, what was important for Bar ${ }^{\mathrm{e}}$ Ebroyo and his correligionists, this was a multi-religious, multi-national order which was not dominated by Islam and in which the Syriac-speaking Christians

${ }^{99}$ On the name, A. Boyle, "On the Titles Given in Juvainî to Certain Mongolian Princes," HJAS 19 (1956): 146-54, here 153; Spuler (1985) 38 n. 58.

100 Chron. [Bruns-Kirsch] 492.9, [Bedjan] 465.6f., [Çiçek] 421a 3f. (cf. Fiey [1975a] 14; Hage [1988] 73).-We might also remember in this connection such items as Bar 'Ebroyo's reference to Hulagu and his wife Doquz [Ṭoquz] Khatun as those "who made the Christian faith triumph" (mnașhone d-tawdito mshiboyto, Chron. [Bedjan] 521.18; in connection with the notion of the "triumph" [neșhono] of the Christians, cf. also ibid. 540.2, and Fiey [1975a] 50) and his constant reference to Doquz Khatun as the "believing queen" and "a true Christian" (Chron. [Bedjan] 491.15f., 509.21f., 521.16, Chron. eccl. II.439.9, Mukhtașar târîkh al-duwal [ed. 1958] 263.17; cf. Lane [1999] \$32 with n. 49; this latter an interesting point also in connection with Bar 'Ebroyo's ecumenical attitude, given that Doquz Khatun was a "Nestorian").- - On an illustration in a manuscript copied at Mar Mattai in 1260 (Vat. syr. 559, fol. 223v) where Constantine and Helena appear to be identified with Hulagu and Doquz Khatun, see Fiey, "Iconographie syriaque. Hulagu, Doquz Khatun ... et six ambons?," Muséon 88 (1975): 59-68 [= 1975b], here 59-64 (cf. id. [1975a] 23; id. "Nașârâ," EI 7.970-3 [1992], here 973a; Spuler [1985] 59 n. 124; Lane, loc. cit. with n. 47 ; the anonymous referee kindly informs me that he/she recently had a correspondent confirm the date of Vat. syr. 559 indeed to be 1571 A.Gr./1260).- - On the name of Doquz Khatun ("peacock," not “nine”), see Boyle (1975) 40f.; cf. Chron. ed. Bedjan 491 footnote. 
too were given the opportunity, for the first time in centuries, to compete with the other races for positions of prominence. ${ }^{101}$

[46] It is needless to stress in an academic journal such as this the importance of literature, and scientific literature in particular, as a factor contributing to the prestige of a nation. In order for the Syriac-speaking peoples to assert themselves in the new situation, there was a need to update their scientific literature. Bar ${ }^{\mathrm{e}} \mathrm{Ebroyo}$, as the religious and political leader of his people, would, one might assume, have been aware of this situation. Another, who would have been even more acutely aware of the situation in view of his position at the court and the daily contact he would have had there with those of other cultures, is Simeon.

In his preface to the Suloqo hawnonoyo, Bar ${ }^{\mathrm{e}}$ Ebroyo describes Simeon as "one who, in our palaces, rebuilds on the ruins of the sciences and one who renews the ancient disciplines in our age."102 Elsewhere in his works Bar "Ebroyo talks of the neglect of knowledge and the ruinous state of the sciences ${ }^{103}$ and by this Bar EEbroyo presumably means the neglect of scientific literature in Syriac, since Arabic writing, though past its golden age, was still in a relatively healthy state in the 13th century. When Bar ${ }^{e}$ Ebroyo talks of Simeon as a renewer of those ancient disciplines, therefore, this implies that Simeon took an active interest in promoting Syriac writing. If this is the case, it may be to the influence of Simeon that

101 The care taken to mention Christian and Zoroastrian dating in the introduction to Țusi's Zî̀-i îlkhânîhas been taken as exemplifying a certain sensitivity for this new order of things (see A. Boyle, "The Longer Introduction to the 'Zij-i-Ilkhani' of Nasir-ad-Din Tusi," JSSt 8 [1963]: 244-54, here 252f.).

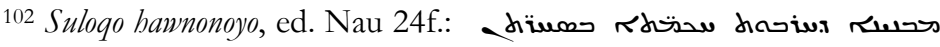

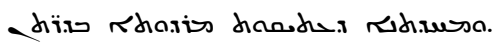

${ }^{103}$ So in the oft-cited preface to Mnorat qudshe; see e.g. ed. Bakos 24.11f., ed. Çiçek 23.16-8: “... the field of wisdom has grown waste, the love of wisdom has grown cold; its fire has been extinguished and its light has grown dark" (cf. R. Duval, La litterature syriaque, 3rd ed. [Paris, 1907, rep. Amsterdam: Philo, 1970] 408; P. Sbath, "Manuscrits orientaux de la bibliothèque Asbat," ROC 29 [1920/1]: 194-205, 288-305, here 199; Janssens [1937], 3; C. Sélis, Les Syriens orthodoxes et Catholiques [Turnhout: Brepols, 1988] 70).-Cf. also the passage concerning the neglect of historiography in the preface to Chron., ed. Bedjan 2.1-10. 
we owe, in part at least, the decision of one of the greatest writers in Syriac to choose that language as the language of his writings.

\section{CONCLUSION}

[48] It will have to be admitted here that much of what has been said above belongs to the realm of speculation. What is certain is that Rabban Simeon of Qalea Rumaita, who worked as a physician at the Ilkhanid court in the period between 1260 and 1289, exercised considerable influence on the affairs of the Syriac Orthodox Church during that period-to the extent that he was able to see his own nephew raised to the supreme office in that church-, and that Bar ${ }^{\mathrm{E}}$ Ebroyo had close dealings with this Simeon throughout his maphrianate as one who had worked with him as a physician at the Ilkhanid court at one time, as a frequent visitor to Azerbaijan and the Ilkhanid court, ${ }^{104}$ and as the tutor to Simeon's son, Taj alDaula, and his nephew and future patriarch, Nemrod. It is also certain that two of Bar 'Ebroyo's works were written specifically at Simeon's request. Beyond that the role played by Simeon in the composition of Bar 'Ebroyo's works remains uncertain, but it is hoped that the discussions above suffice to show that there is a likelihood that he did play a significant role and that the influence of Simeon is a factor worth bearing in mind when considering the background to the genesis of the Bare ebraean corpus as a whole, as well as of the individual works.

104 Bar ${ }^{e}$ Ebroyo was in (Persian) Azerbaijan for prolonged periods on at least four occasions during his maphrianate, viz., 1) in 1268 in Tabriz and Maragha (Chron. eccl. II.441.25-443.3); 2) from summer 1272 for one year in Maragha (II.443.16-20); 3) in Lent 1279 in Maragha (II.447.21f.), perhaps remaining there until spring 1282 when he moved to Tabriz via the Mongol camp at Alataq (II.453.7-455.2) and probably remaining then in Tabriz until he set out for Nineveh in 1283 (II.457.5-7); 4) in 1286 to Maragha (II.467.9-ult.), where he died on 30th July (II.473.7-10).-Cf. Fiey (1973) 430, 432-4; Gusejnov (1960) 56, 87-89.--Fiey is mistaken when he talks of Bar ${ }^{e}$ Ebroyo travelling from Baghdad to Maragha in 1277 (op. cit. p. 433). The note in ms. Cantab. Gg. 3.30 mentioning Bar 'Ebroyo's journey to Maragha belongs, not to the text of the Mimro zangonoyo as Fiey thought, but to that of the Talyut hawno, the journey referred to there being, in fact, the journey of 1286 (see Wright-Cook [1901] 1024). 


\section{BIBLIOGRAPHY}

'Abbâs, Ihsân. Fawât al-wafayât wa-l-dhail 'alaihâ. Ta'lif Muhammad b. Shâkir al-Kutubî (764 h.), 5 vols. Beirut: Dar Sader, 1974.

Abbeloos, Joannes Baptista, \& Thomas Josephus Lamy. Ktobo d-eqlesiyastiqi d-sim l-Mor Griguriyus mafryono d-madnho d-bu Abu al-Farag. Gregorii Barbebraei Chronicon ecclesiaticum, 2 parts (3 vols.). Louvain: Peeters, $1872-7$.

'Abd al-Hamîd, Muhammad Muhyi al-Dîn. Fawât al-wafayât. Ta'liff Mubammad b. Shâkir b. Ahmad al-Kutubî al-mutawaffâ fí âm 764 min al-hijra wa-buva dhail 'alâ Kitâb 'Wafayât al-áyân'"li-Ibn Kballikân, 2 vols. Cairo: Maktabat al-Nahḍat al-Mișrîya, 1951.

Alkan, Cercis. Ktobo d-yawno metul dubore d-ibidoye b-karyoto. Güvercin Kitabi. Yalniəliga cekilenlerin kisaca tedbirleri: (Ebûl-Farac) diye tanimlanan Dogu Mafiryani Aziz Mor Gregoriyos'un eserlerindendir. Glane/Losser: Bar Hebraeus Verlag, 1989.

Anonymous. "Der Uebergang der Oberherrschaft von den Ommaiaden auf die Abbasiden, nach dem syrischen und arabischen Texte des Abu-l-Faradsch zusammengestellt." Fundgruben des Orients (Vienna) 5 (1816): 346-50.

Arberry, Arthur J. The Chester Beatty Library. A Handlist of Arabic Manuscripts, 8 vols. (vol. 8: "Indexes" by Ursula Lyons). Dublin: Walker (vol. 1-2), Hodges, Figgis \& Co. (vol. 3-8), 1955-66.

Armalet [Armala], Ishâaq. "Târîkh al-duwal al-suryânî ta"lîf Abî al-Faraj alMalațî." Machriq 43 (1949): 463-502; 45 (1951): 25-70, 181-99, 351-64, 517-32; 46 (1952): 7-28, 385-400, 514-54; 47 (1953): 3-25, 423-70; 48 (1954): 418-57; 49 (1955): 736-49; 50 (1956): 3-16, 129-52, 257-74, 385-414 [The edition, Beirut: Dâr alMashriq, 1986, with preface by J.M. Fiey, was inaccessible to me].

Ashtor, Eliyahu. Histoire des prix et des salaires dans l'Orient médiéval. Paris: S.E.V.P.E.N., 1969.

Assemani, Joseph Simonius, B.O. = Bibliotheca Orientalis ClementinoVaticana, 3 vols. Rome: S. Cong. de Propaganda Fide, 17191728. Rep. Hildesheim/New York: Olms, 1975.

Assemani, Stephanus Evodius. Bibliothecae Mediceae Laurentianae et Palatinae codicum MSS orientalium catalogus. Florence: Albizinianus, 1742.

Assemani, Stephanus Evodius, \& Joseph Simonius Assemani. Bibliothecae Apostolicae Vaticanae codicum manuscriptorum catalogus, part I., vols. II-III. Rome: Typographia linguarum orientalium, 1758-9. Rep. Paris: Maisonneuve, 1926.

Bakos, Ján, Le candélabre des sanctuaires de Grégoire Aboulfaradj dit Barbebraeus. PO, 22 (fasc. 4), 489-628; PO, 24 (fasc. 3), 295-439, Paris: Firmin-Didot, 1930-3 [cited according to the continuous pagination given to the two fascicles, pp. 1-285]. 
Barșaum, Patr. Ignatius Ephrem I. Lu'lu' = Al-lu'lu’ al-manthûr fî̀ târîkh al'ulûm wa-l-âdâb al-suryânîya. Histoire des sciences et de la littérature syriaque, 2nd ed. Aleppo, 1956. Rep. Glane/Losser: Bar Hebraeus Verlag, 1987.

Maktbonuto d- al atro d-Tur 'Abdin. Târikh Tûr 'Abdin (with Arabic translation by G. B. Behnam). Jounieh: Biban, 1964. Rep. (Syriac only, with continuation by J.Y. Çiçek), Glane/Losser: Bar Hebraeus Verlag, 1985 (Tur'Abdin Taribi).

Risâla fî 'ilm al-nafs al-insânîya li-l-'allâma Mâr Ghrîghûriyûs Ibn al'Ibrî mafriyân al-mashriq. Jerusalem: Mațbaea Dair Mâr Marqûs, 1938.

Baumstark, Anton. GSL = Geschichte der syrischen Literatur mit Ausschluß der christlich-palästinensischen Texte. Bonn: Marcus und Weber, 1922.

Bedjan, Paul. Ktâbâ d-maktbânût zabnê d-sîm l-Mâr Grîgôrîyôs Bar 'Ebrâyâ. Gregorii Barbebraei Chronicon syriacum. Paris: Maisonneuve, 1890.

- Ktâbâ d-Îtîqûn d-al myattrût dubbârê men syâmê d-Bar ${ }^{c}$ Ebrâyâ. Ethicon, seu Moralia Gregorii Barbebraei and Ktâbâ d-yawnâ mettul dubbârê dîhîdâyê men syâmê d-Bar 'Ebrâyâ. Liber columbae seu Directorium monachorum Gregorii Barhebraei. Paris/Leipzig: Harrassowitz, 1898.

Ktâbâ d-buddâyê men syâmê d-Bar 'Ebrâyâ. Nomocanon Gregorii Barhebraei, Paris/Leipzig: Harrassowitz, 1898.

Bernhard, Ludger. Die Chronologie der syrischen Handschriften. VOHD Suppl., 14. Wiesbaden: Steiner, 1971.

Boyle, John Andrew. MWE = The Mongol World Empire 1206-1370. London: Variorum, 1977.

"On the Titles Given in Juvainî to Certain Mongolian Princes." HJAS 19 (1956): 146-54. Rep. in id., MWE, no. XVII.

The History of the World-Conqueror by ${ }^{\natural}$ Ala-ad-Din 'Ata-Malik Juvaini. Translated from the text of Mirza Muhammad Qazvini. Manchester: Manchester University Press, 1958.

"Kirakos of Ganjak on the Mongols." CAsJ 8 (1963): 199-214. Rep. in id., $M W E$, no. XIX.

Boyle, J.A. "The Longer Introduction to the 'Zij-i-Ilkhani' of Nasir-adDin Tusi." JSSt 8 (1963): 244-54. Rep. in id., MWE, no. XXVII.

"Some Additional Notes on the Mongolian Names in the History of the Nation of Archers." In L. Ligeti, ed. Researches in Altaic Languages: papers read at the 14th meeting of the Permanent International Altaistic Conference, beld in Szeged, August 22-28, 1971, 33-42. BOH, 20. Budapest: Akad. Kiadó, 1975. Rep. in id., MWE, no. XXXII.

Braun, Oskar. Moses bar Kepha und sein Buch von der Seele. Freiburg: Herder, 1891.

Brock, Sebastian P., "Two Syriac Manuscripts in the Library of Selwyn College, Cambridge.” OrChr 55 (1971): 149-60. 
Brockelmann, Carl. GAL = Geschichte der arabischen Literatur, 2nd ed. 2 vols. Leiden: Brill, 1943; Supplement, 3 vols., Leiden: Brill, 1937-42. Rep. Leiden/New York/Cologne: Brill, 1996.

Bruns, Paulus Jacobus. De rebus gestis Richardi Angliae regis in Palaestina. Excerptum ex Gregorii Abulpharagii Chronico syriaco. Oxford: Fletcher/Prince \& Cooke, London: White \& Payne, 1780.

Bruns, Paulus Jacobus, \& Georgius Guilielmus Kirsch. Ktobo d-maktbonut zabne d-sim l-Mor Griguriyus Bar 'Ebroyo. Bar-Hebraei Chronicon Syriacum. Leipzig: A.F. Boehme, 1789.

Budge, Earnest A. Wallis. The Chronography of Gregory Abûll Faraj, the son of Aaron, the Hebrew physician, commonly known as Bar Hebraeus, 2 vols. Oxford: Oxford University Press / London: Humphrey Milford, 1932 [The references above unless otherwise indicated are to vol. 1].

Cahen, Claude. "Une famille byzantine au service des Seljuqides d'AsieMineure." In P. Wirth, ed. Polychronion. Festschrift. F. Dölger zum 75. Geburtstag, 145-9. Heidelberg: Winter, 1966. Rep. in id., Turcobyzantina et Oriens Christianus. London: Variorum, 1974, no. VIII.

Cardahi, Gabriel. Ktobo d-yawno da- bid l-Mor Grigoriyos mafryono d-madnho dbu Abu-l-Farag Bar ÉEbroyo. Abulfaragii Gregorii Bar-Hebraei Mafriani Orientis Kithâbhâ dhiyaunâ seu Liber columbae. Rome: Typ. Academiae Lynceorum, 1898.

Cheikho, Louis. "Al-Nafs al-basharîya. Maqâla mukhtașara șannafahâ alab al-eârif bi-Allâh Abû al-Faraj al-ma erûf bi-Ibn al-'Tbrî.” Machriq 1 (1898): 745-9, 828-33, 934-8, 1084-7, 1113-20. Also published as appendix to id., Nubdha fì tarjama wa-ta âlîf al- 'allâma Ghrîghûriyûs Abî al-Faraj b. Abrûn al-tabîb al-Malatî al-ma 'rûf bi-Ibn

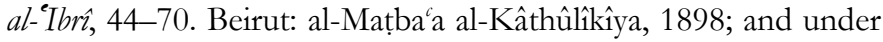
the title "Maqâla mukhtașara fî eilm al-nafs al-basharîya" in L. Malouf, C. Eddé \& L. Cheikho, eds. Traités inédits d'anciens philosophes arabes musulmanes et chrétiens, 2nd ed., 76-102. Beirut: Imprimerie catholique, 1911 [and elsewhere, see Graf, GCAL II.274].

Cheikho, L. Kitâb al-makhtụtât al- arabîya li-katabat al-nașranîya. Catalogue des manuscrits des auteurs arabes chrétiens depuis l'Islam. Beirut, Imprimerie catholique, 1924.

Çiçek, Julius Yeshuc. Ktobo d-yawno metul dubore d-ibidoye b-karyoto men syome dabun tubtono Mor Griguriyus mafryono qadisho d-madnho d-metidac Bar 'Ebroyo.Bar Hebraeus's Book of the Dove. Glane/Losser: Bar Hebraeus Verlag, 1983.

Mimro al qadisho Griguriyus mafryono d-madnho da-bid l-Diyusqurus episqupo d-Gozarto mdito d-Qardu shnat 1286 m. Bar Hebraeus. Glane/Losser: Bar Hebraeus Verlag, 1985. 
Çiçek, Julius Yeshuc. Hudoye mețl qonune idtonoye w-nomuse ólmonoye men syome d-abun yadutono Mor Griguriyus Yuhanon mafryono mshabho dmadnho d-idto suryoyto trișat shubho d-Antiyuk. Nomocanon of BarHebraeus. Glane/Losser: Bar Hebraeus Verlag, 1986.

Maktbonut zabne men risho da-brito 'damo la-shnat $1285 \mathrm{~m}$. d-sim lyadu tono rabo Mor Griguriyus Yubanon mafryono mshabho d-madnho d-metdalal Bar Ebroyo. The Chronography of Bar Hebraeus. Glane/ Losser: Bar Hebraeus Verlag, 1987.

Mnorat qudshe metul shetese idtonoyoto d-Yuhanon Bar 'Ebroyo mafryono d-madnho. Mnorath kudshe (Lamp of the Sanctuary) by Mor Gregorios Yohanna Bar Ebryoyo. Glane/Losser: Bar Hebraeus Verlag, 1997.

Cleaves, Francis Woodman, "The Mongolian Names and Terms in the History of the Nation of the Archers by Grigor of Akanc.." HJAS 12 (1949): 400-43.

Colpe, Carsten. "Bar Hebräus über die Manichäer.” In E. Dassmann \& K.S. Frank, ed. Pietas. Festschrift für Bernhard Kötting, 237-42. JAC.E, 8. Münster: Aschendorff, 1980.

Conrad, Lawrence I. "On the Arabic Chronicle of Bar Hebraeus: His Aims and Audience." ParOr 19 (1994): 319-78.

Darley-Doran, R.E. "Tûmân 2." EI² X.619-21 (1999).

Dédéyan, Gérard. La chronique attribuée au Connétable Smbat. DRHC, 13. Paris: Geuthner, 1980.

Dolabani, Philoxenus Yûhannâ. Mushhoto d-Mor Griguriyus Yuhannon Bar EEbroyo mafryono d-madnho. Dînân al-'allâma al-kabîr wa-l-shâiir alfailasûf al-suryânî Mâr Ghrîghûriyûs Yûhannâ Ibn al-'ibrî mafriyân almashriq. Jerusalem: Mațba a Dair Mâr Marqûs, 1929. Rep. Glane/ Losser, 1983 (Bar Hebraeus' Mush'hotho Book).

(ed. G.Y. Ibrahim). Fibris makbțutât Dair Mâr Marqus. Mḥawyono d-ktobe srite d-bet arke d-Dayro d-Mor Marqus_Ureshlem. Catalogue of Syriac Manuscripts in St. Mark's Monastery (Dairo DMor Marqos). Syriac Patrimony, 8. Aleppo: Mardin Publishing House, 1994.

Dolabani, Philoxenus Yûhannâ, René Lavenant, Sebastian Brock \& Samir Khalil Samir. "Catalogue des manuscrits de la bibliothèque du Patriarcat Syrien Orthodoxe à Homṣ (Auj. à Damas).” ParOr 19 (1994): 555-661.

Dulaurier, Édouard. "Extraits de la Chronique de Michel le syrien." JA $4^{e}$ sér. 12 (1848): 281-334; 13 (1849): 315-76.

Duval, Rubens. La littérature syriaque, 3rd ed. Paris, 1907. Rep. Amsterdam: Philo, 1970.

Fiey, Jean-Maurice. “Âḍarbâygân chrétien.” Muséon 86 (1973): 397-435. Chrétiens syriaques sous les Mongols (Il-Khanat de Perse, XIII-XIV ${ }^{e}$ s.). CSCO, 362, subs. 44. Louvain: Secrétariat du Corpus SCO, 1975 [= 1975a . 
Fiey, Jean-Maurice. "Iconographie syriaque. Hulagu, Doquz Khatun ... et six ambons?” Muséon 88 (1975): 59-68 [= 1975b].

“Esquisse d'une bibliographie de Bar Hébraeus (+1286)." ParOr 13 (1986): 279-312.

"Nașârâ.” EI2 7.970-3 (1992).

- Pour un Oriens Christianus novus. Répertoire des diocèses syriaques orientaux et occidentaux. Beiruter Texte und Studien, 49. Beirut/Stuttgart: Steiner, 1993.

Flügel, Gustav. Lexicon bibliographicum et encyclopaedicum a Mustafa ben Abdallah Katib Jelebi dicto et nomine Haji Khalfa celebrato compositum, 7 vols. Leipzig/London: Oriental Translation Fund, 1835-58. Rep. New York/London: Johnson Reprint Corporation, 1964.

Furlani, Giuseppe. "Barhebreo sull' anima razionale (Dal Libro del Candelabro del Santuario)." Or. NS 1 (1932): 1-23, 97-115.

Göttsberger, Johann. Barhebräus und seine Scholien zur Heiligen Schrift. BSt(F), 5/4-5. Freiburg: Herder, 1900.

- "Die syro-armenischen und die syro-koptischen Bibelcitate aus den Scholien des Barhebräus." $Z A W 21$ (1901): 101-41.

Gusejnov [Hüsejnov], R. Sirijskie istocniki XII-XIII vv. ob Azerbajdzane. XII-XIII äsrlärdä surija mänbäläri Azerbajcan hagginda. Baku: Izd. Akademii Nauk Azerbajdzzanskoj SSR, 1960.

Graf, Georg. GCAL = Geschichte der christlichen arabischen Literatur, 4 vols. StT, 118, 133, 146, 147. Vatican City: Bibl. Apost. Vaticana, 1944-51.

Hage, Wolfgang. “Gregorius Barhebräus.” In M. Greschat, ed. Gestalten der Kirchengeschichte IV. Mittelalter II, 63-72. Stuttgart/Berlin/ Cologne/Mainz: Kohlhammer, 1983.

- Syriac Christianity in the East. Moran 'Eth'o, 1. Kottayam: SEERI, 1988. Rep. ibid. 1997.

Hammer-Purgstall, Josef von. Geschichte der Ilchane, das ist der Mongolen in Persien, 2 vols. Darmstadt: Leske, 1842-3.

Honigmann, Ernest. Le couvent de Barșaumâ et le patriarcat jacobite d'Antioche et de Syrie. CSCO, 146, subs. 7. Louvain: L. Durbecq, 1954.

Hubaiqa [Hobeica], Yûsuf. "Kitâb al-ḥamâma li-Ibn al-eIbrî." Machriq 50 (1956): 17-66.

Janssens, Herman F. L'entretien de la sagesse, Introduction aux oeuvres philosophiques de Bar Hebraeus. BFPUL, 75. Liège: Faculté de Philosophie et Lettres, 1937.

Jahn, Karl. Ta'rîh-i-Mubârak-i-Gẫânî des Rasîd al-Dîn Faḍl Allâh Abî-l-Hair. Geschichte der Ilhâne Abâgâ bis Gaihâtû (1265-1295). Abh. der deutschen Gesellschaft der Wissenschaften und Künste in Prag, philos.-hist. Abt. I, Prague, 1941. Rep. CAS 2, The Hague: Mouton \& Co., 1957. 
Kawerau, Peter, Die jakobitische Kirche im Zeitalter der syrischen Renaissance. Idee und Wirklichkeit. BBA, 3, Berlin: Akademie-Verlag, $1960^{2}$.

Khoury, Joseph. Une synthèse de christologie jacobite: la 'quatrième base' du 'Candélabre des sanctuaires' de Grégoire Aboulfaradj dit Barhebraeus, 2 vols. (I. Présentation; II. Traduction du texte). Diss. Institut Catholique de Paris, 1950 (unpublished).

- Le candélabre du sanctuaire de Grégoire Abou'lfaradj dit Barbebraeus. Quatrième base: de l'Incarnation. PO, 31.1, 1-268. Paris: FirminDidot, 1965.

Koffler, Hubert. Die Lehre des Barhebräus von der Auferstehung der Leiber. $\operatorname{OrChr}(\mathrm{R}), 28 / 1$. Rome: Pont. Institutum Orientalium Studiorum, 1932.

Krause, Max. "Stambuler Handschriften islamischer Mathematiker." Quellen und Studien zur Geschichte der Mathematik, Astronomie und Physik, Abt. B, 3 (1936): 437-532. Rep. in Fuat Sezgin, ed. Beiträge zur Erschliessung der arabischen Handschriften in Istanbul und Anatolien, 3 vols. + index. Frankfurt: IGAIW, 1986. II.683-778.

Kurdian, H. "A Few Corrections in the English Translation and Transliteration of the Chronography of Gregory Abû'l Faraj (Bar Hebraeus)." JRAS (1938): 431.

Lane, George. "An Account of Gregory Bar Hebraeus Abu al-Faraj and his Relations with the Mongols of Persia." Hugoye, 2.2 (July 1999).

Langlois, Victor. Chronique de Michel le Grand, patriarche des syriens jacobites, traduite pour la première fois sur la version arménienne du prêtre Ischôk. Venice: l'Académie de Saint-Lazare, 1868.

Lantschoot, Arnold van. Inventaire des manuscrits syriaques des fonds Vatican (490-631) Barberini oriental et Neofiti. StT, 243. Vatican City: Bibl. Apost. Vaticana, 1965.

al-Manșûr, Khalîl (notes by). Târîkh mukhtașar al-duwal. Ta'lîf al-'allâma Ab̂̀ al-Faraj Ghrîghîriŷus b. Abrûn al-Malațî al-márûf bi-Ibn al-'Ibrî almutawaffâ sana 685 h. Beirut: Dâr al-Kutub al-Tlmîya, 1997.

Mahé, J.P., review article 'Isox, Girk' i veray bnut'ean (Livre sur la nature), texte critique, introduction et traduction russe de $\mathrm{S}$. VARDANYAN, Erévan (Matenadaran) 1979, ...” REArm NS 14 (1980): 524f.

Margoliouth, David Samuel. Analecta orientalia ad Poeticam Aristoteleam. London: Nutt, 1887. Rep. Hildesheim/Zürich/New York: Olms, 2000.

Meyerhoff, Max, \& G.P. Sobhy. The Abridged Version of "The Book of Simple Drugs" of Ahmad Ibn Muhammad al-Ghâfiqî by Gregorius Abu'l-Farag (Barhebraeus). Muntakhab kitâb jâmi al-mufradât li-Aḥmad b. Muhammad b. Khalîd al-Ghâfiqî al-mutawaffâ fì naḅw sana 560 h., intakhabahu Abû al-Faraj Ghrîghîriyûs al-márûf bi-Ibn al- Ibrî al- 
mutawaffâ fî sana 684 h., vol. 1, fasc. 1-4 (no more published). Cairo: Government Press, 1932-40. Rep. Frankfurt: IGAIW, 1996.

Mingana, Alphonse. The Catalogue of the Mingana Collection of Manuscripts now in the Possession of the Woodbrooke Settlement, Selly Oak, Birmingham, vol. I, Syriac and Garshûni Manuscripts. Cambridge: Heffner, 1933.

Nallino, Carlo Alphonso. "Il diritto musulmano nel Nomocanone siriaco cristiano di Barhebreo." RSO 9 (1922/3): 512-80. Reprinted with corrections in id., Raccolta di scritti editi e inediti, vol. 4, 214 290. Rome: Istituto per l'Oriente, 1942.

Nau, François. Ktobo d-suloqo hawnonoyo ál dmuto da-rqie w-aro men syome $d$ Mor Griguriyus Bar ÉEroyo mafryono d-madnho. Le livre de l'ascension de l'esprit sur la forme du ciel et de la terre. Cours d'astronomie rédigé en 1279 par Grégoire Aboulfarag, dit Bar-Hebraeus. BEHE.H, 121, part 1 (text), Paris: Firmin-Didot, 1899; part 2 (translation), Paris: Bouillon, 1899.

- "La cosmographie au VII e siècle chez les Syriens." ROC 15 (1910): 225-54.

Nöldeke, Theodor. Orientalische Skizzen. Berlin: Paetel, 1892. Rep. Hildesheim: Olms, 1974.

Ömer Riza Dogrul. Gregory Abû'l-Farac (Bar Hebraeus). Abû'l-Farac Taribi. TTKY, 2/2, 2 vols. Ankara, 1945-50. Rep. Ankara: Türk Tarih Kurumu Basimevi, 1987.

Panicker, Mathunny John. Christology of Bar Ebraya (Yubanon Gregorius Abu'l Faraj), excerpta ex Dissertatione ad Doctoratum in Facultate Scientiarum Ecclesiasticarum Orientalium. Rome: Pont. Institutum Studiorum Orientalium, 1995.

Payne Smith, Robert. Catalogi codicum manuscriptorum Bibliothecae Bodleianae pars sexta, codices syriacos, carshunicos, mendaeos complectens. Oxford: Clarendon, 1864.

Perini, David Aurelio. "Catalogo dei codici manoscritti ed oggetti portati dall' Oriente nel 1879 dal P. Agostino Ciasca Agostiniano.” Bess. ser. 2, 6 (1904): 58-71, 258-81.

Petrushevsky, I.P. "The Socio-Economic Conditions of Iran under the ÎlKhâns." In J.A. Boyle, ed. The Cambridge History of Iran, vol. 5, 483-537. The Seljuq and Mongol Periods. Cambridge: Cambridge University Press, 1968.

Pinggéra, Karl. "Christologischer Konsens und kirchliche Identität. Beobachtungen zum Werk des Gregor Bar Hebraeus.” OstKSt 49 (2000): 3-30.

Quatremère, Étienne. Histoire des mongols de la Perse écrite en persan par Raschid-Eldin, tome premier (no more published). Paris: Imprimerie royale, 1836. 
Raes, Alphonse. "XV. Anaphora minor Sancti Iacobi, fratris Domini.” In Anaphorae syriacae, vol. 2, fasc. 2, 181-210. Rome: Pont. Institutum Orientalium Studiorum, 1953.

Ragep, Faiz J. Nasîr al-Dîn Tûsî's Memoir on Astronomy (al-Tadbkira fì 'ilm albay'a), 2 vols. New York/Berlin/Heidelberg: Springer, 1994.

Reller, Jobst. Mose bar Kepha und seine Paulinenauslegung nebst Edition und Übersetzung des Kommentars zum Römerbrief. GOF.S, 35. Wiesbaden: Harrassowitz, 1994.

Șâlhânî, Anțûn. Târîkh mukhtașar al-duwal li-l- allâma Ghrîghûrìûs al-malațî almá rûf bi-Ibn al-Ibrî. Beirut: al-Mațba'a al-Kâthûlîkîya, $1958^{2}$.

Samir, Samir Khalil. "Cheminement mystique d'Ibn al-'Ibrî (1226-1286)." POC 37 (1987): 71-89.

Sauma, Assad. "Commentary on the 'Biography' of Bar Hebraeus." Aram (Stockholm, Arameiska Akademikernas Förbund) 7 (1998): 3568.

Sayili, Aydin. "Khwâja Nașîr-i Ṭûsî wa rașadkhâna-i Marâgha (Nasîr-udDîn-i-Tûsî ve Merâga Rasathanesi)." AÜDFD 14 (1956): no. 12, p. 1-12, and plate facing p. 16.-The same article also in Yâdnâma-i Khwâja Nașîr al-Dîn Tûsî. Le Mémorial de Khwâdjah Nassîr al-dîn Toûssi, vol. 1, 57-75. Intishârât-i Dânishgâh-i Tihrân, 416. Teheran: Imprimerie de l'Université de Téhéran, 1336 h.sh./1957.

The Observatory in Islam and its Place in the General History of the Observatory. TTKY, VII/38a. Ankara: Türk Tarih Kurumu Basimevi, $1988^{2}$.

Sbath, Paul. "Manuscrits orientaux de la bibliothèque Asbat." ROC 20 (1920/1): 194-205, 288-305.

—. Mukhtașar fî̀ ilm al-nafs al-insânîya li-Ghrîghûriyûs Abî al-Faraj almárûf bi-Ibn al-'brî. Traité sur l'âme par Bar-Hebraeus Mort en 1286. Cairo: Friedrich, 1928.

Sbath, P. "Manuscrit arabe sur la pharmacopée hippiatrique." Bulletin de l'Institut d'Égypte 14 (1931/2): 79-81.

Al-Fibris (Catalogue de manuscrits arabes), 3 parts \& supplement. Cairo: Imprimerie Al-Chark, 1938-40.

Scebabi, Augustinus. Gregorii Bar-Hebraei carmina. Mushboto da-bidon lmafryono Griguriyus Bar E Ebroyo. Rome, 1877.

Scher, Addai. "Notice sur les manuscrits syriaques du Musée Borgia, aujourd'hui à la Bibliothèque Vaticane." JA 10e sér. 13 (1909): 249-87.

Schmidt, Andrea B. "Die zweifache armenische Rezension der syrischen Chronik Michaels des Großen.” Muséon 109 (1996): 299-319.

"Syrische Tradition in armenischer Adaption. Die armenische Rezeption des Geschichtswerks von Michael Syrus und der antichalcedonische Judenbrief an Kaiser Markianos." In 
R. Lavenent, ed. Symposium Syriacum VII, 359-371. OCA, 256. Rome: Pont. Istituto Orientale, 1998.

Schultess, Friedrich, review article "Göttsberger, J., Barhebraeus und seine Scholien zur Heiligen Schrift. ..." GGA 164 (1902): 161-8.

Sélis, Claude. Les Syriens orthodoxes et Catholiques. Fils d'Abraham. Turnhout: Brepols, 1988.

Sezgin, Fuat. $G A S=$ Geschichte des arabischen Schrifttums, vols. 1-9. Leiden: Brill, 1967-84, Index, Frankfurt: IGAIW 1995, vols. 10-12, Frankfurt: IGAIW, 2000.

Sherwood, Polycarpe. "Le fonds patriarcal de la bibliothèque manuscrite de Charfet." OrSyr 2 (1957): 93-107.

Sony, Behnam. Fibris al-makbțutât al-batriyarkîya fî Dair al-Sharfa-Lubnân. Le catalogue des manuscrits du Patrarcat au Couvent de Charfet-Liban. Beirut, 1993.

Spuler, Bertold. "Djuwaynî, Șhams ad-Dîn Muhammad b. Muhammad." EI² II.607 (1963).

- Die Mongolen in Iran. Politik, Verwaltung und Kultur der Ilchanzeit 1220-1350. Leiden: Brill, $1985^{4}$.

Sümer, Faruk. "Anadolu'da Mogollar." Selçuklu Araștirmalari Dergisi (Ankara) 1 (1970): 1-147.

Suter, Heinrich. Die Mathematiker und Astronomen der Araber und ibre Werke. Bio-bibliographische Übersicht von Wissenschaftlern der arabischen Welt vom achten bis zum siebzehnten Jahrhundert. Abh. z. Gesch. d. mathematischen Wissenschaften, 10. Leipzig: Teubner, 1900. Rep. Amsterdam: APA Oriental Press, 1981.

Ter-Minassiantz, Erwand. Die armenische Kirche in ibren Beziehungen zu den syrischen Kirchen bis zum Ende des 13. Jabrbunderts. TU NF, 11/3. Leipzig: Hinrich, 1904.

Teule, Hermann G.B. Gregory Barbebraeus. Ethicon (Mêmrâ I). CSCO, 534 535, syr. 218-9. Louvain: Peeters, 1993.

Thomson, Robert W. "The Historical Compilation of Vardan Arewelc'i." DOP 43 (1989): 125-226.

- A Bibliography of Classical Armenian Literature to 1500 AD. CChr. Turnhout: Brepols, 1995.

Tisserant, Eugène Card. "Michel le syrien.” DThC X (1929): 1711-19

Vardanyan, Stella A. Ișoch. Kniga o prirode. Ișôh. Girk' i veray bnut'ean. Erevan: Izd. Akademii Nauk Armjanskoj SSR, 1979.

"Ancient Armenian Translations of the Works of Syrian Physicians." REArm. NS 16 (1982): 213-9.

Vööbus, Arthur. Syrische Kanonensammlungen. Ein Beitrag zur Quellenkunde. I Westsyrische Originalurkunden. 2 vols. (with continuous pagination). CSCO, 307, 317, subs. 35, 38. Louvain: Secrétariat du Corpus SCO, 1970. 
Wensinck, Arent Jan. Bar Hebraeus' Book of the Dove together with some Chapters from his Ethikon. Leiden: Brill, 1919.

Wiedemann, Eilhard. "Zum Leben von Nașîr al Dîn al Ṭûș̂̀” (Beiträge zur Geschichte der Naturwissenschaften LXXV). Sitzungsberichte der physikalisch-medizinischen Sozietät zu Erlangen, 58/59 (1926/7): 363379. Rep. in id., Aufsätze zur arabischen Wissenschaftsgeschichte. Hildesheim/New York: Olms, 1970. II.677-693.

Wright, William. A Short History of Syriac Literature. London: Black, 1894.

Wright, William, \& Stanley Arthur Cook. A Catalogue of the Syriac Manuscripts Preserved in the Library of the University of Cambridge. Cambridge: Cambridge University Press, 1901.

"X." review article "Gregorii Abulpharagii sive Bar Hebraei Chronicon Syriacum ... descripsit ... Paulus Iacob Bruns ... Georg. Guil. Kirsch ..." NOEB 7 (1790): 1-24.

Zolinski, Joseph. Zur Chronographie des Gregorius Abulpharagius. Diss. Heidelberg, Breslau: Th. Schatzky, 1894.

Zonta, Mauro. Fonti greche e orientali dell' Economia di Bar-Hebraeus nell' opera "La crema della scienza." AION.S, 70. Naples: Istituto Universitario Orientale, 1992.

"Structure and Sources of Bar-Hebraeus' 'Practical Philosophy' in The Cream of Wisdom." In R. Lavenant, ed. Symposium Syriacum VII, 279-292. OCA, 256. Rome: Pont. Istituto Orientale, 1998,

Zotenberg, Hermann. Catalogues des manuscrits syriaques et sabéens (Mandaïtes) de la Bibliothèque Nationale. Paris: Imprimerie nationale, 1874. 
